\title{
Uncoupled Precipitation and Water Availability: The Case Study of Municipality of Sfakia, Crete, Greece
}

\author{
Vasileios A. Tzanakakis ${ }^{1, *}$, Aikaterini Pavlaki ${ }^{2,3}$, Emmanouil Lekkas ${ }^{4}$, Emmanouil A. Varouchakis ${ }^{5}$, \\ Nikolaos V. Paranychianakis ${ }^{2}$, Giorgos Fasarakis ${ }^{6}(D)$ and Andreas N. Angelakis ${ }^{7,8}$ (D)
}

\section{check for}

updates

Citation: Tzanakakis, V.A.; Pavlaki,

A.; Lekkas, E.; Varouchakis, E.A.;

Paranychianakis, N.V.; Fasarakis, G.; Angelakis, A.N. Uncoupled

Precipitation and Water Availability: The Case Study of Municipality of

Sfakia, Crete, Greece. Water 2022, 14, 462. https://doi.org/10.3390/ w14030462

Academic Editors: Elias Dimitriou and Athanasios Loukas

Received: 29 October 2021

Accepted: 29 January 2022

Published: 4 February 2022

Publisher's Note: MDPI stays neutral with regard to jurisdictional claims in published maps and institutional affiliations.

Copyright: (C) 2022 by the authors. Licensee MDPI, Basel, Switzerland. This article is an open access article distributed under the terms and conditions of the Creative Commons Attribution (CC BY) license (https:// creativecommons.org/licenses/by/ $4.0 /)$
1 Department of Agriculture, School of Agricultural Science, Hellenic Mediterranean University, 71410 Iraklion, Greece

2 School of Chemical and Environmental Engineering, Technical University of Crete, 73100 Chania, Greece; catrpaul@otenet.gr (A.P.); niko.paranychianakis@enveng.tuc.gr (N.V.P.)

3 Consulting Engineering Bureau of Geological Researches \& Studies, 56 Tzanakaki Str., 73100 Chania, Greece

4 Coastal and Marine Research Laboratory, Foundation for Research and Technology-Hellas, N. Plastira 100, Vassilika Voutes, 70013 Iraklion, Greece; manolislekkas@yahoo.gr

5 Department of Mineral Resources Engineering, Technical University of Crete, 73100 Chania, Greece; evarouchakis@gmail.com

6 Consulting Engineering Bureau, 73100 Chania, Greece; gio.fasarakis@gmail.com

7 Hellenic Agricultural Organization (HAO)_Demeter, Agricultural Research Institution of Crete, 71300 Iraklion, Greece; angelak@edeya.gr

8 Union of Water Supply and Sewerage Enterprises, 41222 Larissa, Greece

* Correspondence: vtzanakakis@hmu.gr

\begin{abstract}
Sfakia is a mountainous municipality located in the southwestern area of the island of Crete, including the southern part of the Lefka Ori Mountain, with an elevation ranging from sea level to over $2400 \mathrm{~m}$. The mountainous massif mainly consists of carbonate rocks and intense karstic phenomena can be observed. The part of the area exceeding over the elevation of $600 \mathrm{~m}$ is characterized by high amounts of precipitation $(1500 \mathrm{~mm})$. Despite this high precipitation, the water availability in the area is low. This work aims to identify the factors that affect the water-resources availability in this area. In addition, issues related to proper water management are presented and discussed that will allow areas with similar characteristics to adapt to climate change. Our study identified the complex geological setting of the area that redirects water away of the hydrological basin (karsts) and the geomorphology that favors precipitation loss through runoff as the most important factors for the low availability of water resources. This paper attempts to create a base of discussion for similar cases worldwide by providing a framework of approaching scientifically analogous problems.
\end{abstract}

Keywords: Crete; karsts; permeability of geological layers; water management; water scarcity

\section{Introduction}

The Mediterranean Basin, and particularly its southern part, encounters significant challenges for the efficient management of limited water resources [1]. Meeting the increasing demands of water requires efficient and integrated management of all existing water resources, including non-conventional ones (treated wastewater and brackish water) and blue water as in other parts of the world [2-4]. The deficit between water supply and demand will exacerbate in the near future, due to the projected climate change [5]. The Mediterranean region is classified among the most vulnerable areas in the world regarding the impacts on climate change on water resources' availability. While the global temperature has increased on average by $1.1^{\circ} \mathrm{C}$ compared to the pre-industrial period, higher increases $\left(1.5^{\circ} \mathrm{C}\right)$ have occurred in the Mediterranean, with an estimated increase rate of $0.03{ }^{\circ} \mathrm{C} /$ year [6]. In addition, increases in the frequency and intensity of extreme events (floods, droughts and heatwaves) have been documented [7,8]. The projected shifts in 
temperature and precipitation patterns will inevitably bring about adverse effects in the limited water resources. These lines of evidence document the need for new management approaches and innovative governance of water resources in order to meet future demands and support sustainable development in rural areas under climate conditions.

The low precipitation heights that are typically concentrated within two or three months during the winter, combined with the high rates of evapotranspiration (ET) are considered responsible for the observed gap between supply and demand. However, this is not always the case, since precipitation often shows great variation in Mediterranean environments [9]. For instance, on the island of Crete, precipitation can range from less than $300 \mathrm{~mm}$ to up to $2500 \mathrm{~mm}$, recording the highest values mostly in high altitude areas. Similar patterns of precipitation variation have been also reported to other parts of the Mediterranean Basin [10]. Apparently, the mean annual (or seasonal) precipitation and ET are critical drivers of water availability [11]; however, other factors, such as the geomorphology and geology of the area, land uses and applied management practices, size and allocation of population and applied water-management plans, are also important [12,13].

The island of Crete, Greece has a remarkable annual overall potential of groundwater $\left(2.2 \times 10^{9} \mathrm{~m}^{3}\right)$ and surface water resources $\left(1,2 \times 10^{9} \mathrm{~m}^{3}\right)$, due to the high average annual precipitation $\left(7.7 \times 10^{9} \mathrm{~m}^{3}\right)$ and the existence of the mountain ranges of "Lefka Ori" (White Mountains), "Psiloritis" and "Dicti", mainly consisting of permeable carbonate bedrock [13]. Significant volumes of water discharge through freshwater springs in the northern perimeter of the "Lefka Ori" Mountains and through brackish water springs in the rest of the coastal part of the island [14]. Unfortunately, despite the large quantities, its shortage for further development is an unpleasant reality. This is directly attributed to the imbalance between the uneven distribution of to-date available water resources in space and time and the uneven distribution of demand in time [12,15]. In order to meet Crete's long-term future water demands, four main Water Resources Planning and Management Schemes have been carried out [13]. They have emerged from the evaluation of alternative scenarios in order to provide the environmentally and value engineering optimal design, in accordance with the EU water requirements and directives [12]. A significant part of these projects has been implemented by securing, in this way, the water supply demands of the cities, as well as a part of the irrigation water requirements. However, there are still areas on Crete where the problem of meeting water needs is still remaining, such as the wider Sfakia area, which is under investigation in the context of this study.

The area of Sfakia extends from the sea level to an elevation up to over $2000 \mathrm{~m}$ and includes the south-central part of the "Lefka Ori" Mountains (Figures 1 and 2), a fact that is related with the current name of the area. According to the prevailing theory, the name is related to the rugged terrain of the area, deriving from the ancient Greek word " $\sigma \varphi \alpha \xi$ ", meaning land chasm or gorge [16]. In the area, there are several gorges (canyons), and among them, the famous Samaria Gorge, the longest one in Europe and the Imvros, which is extended in the coastal area of the south part. The whole area reflects a complex geology that has led to the formation of the "Lefka Ori" Mountains. The latter include significant faults, and various tectonic discontinuities cross its entire massif, the creation of which is relevant to the geological events which were evolved [17-19]. The geological formations in most of the studied area include carbonated rocks which have contributed to the formation of an extended network of karsts and underground aquifers [18,20-22].

Overall, the region receives high amounts of precipitation that reaches up to $2160 \mathrm{~mm}$ per year in average value, as recorded in the east part of the Sfakia area. However, and despite these high precipitation rate, the whole area of Sfakia suffers from low water availability, a fact that has led to competitions and restrictions across different water users; the main users in the Sfakia area and the whole island are the domestic, agricultural and livestock sectors [23]. The issue of low water availability and its efficient management is critical of critical importance for the economic development and sustainability of the area; it needs to be properly investigated and addressed, while also considering the future 
challenges posed by climate change and/or fluctuations, as already evidenced in the island of Crete and other areas of the Mediterranean Basin [6].

The main objectives of this work were to (i) understand the factors affecting the water supply and use in Sfakia area; (ii) identify the current and future challenges in water management, including barriers and constraints; and (iii) propose possible measures to alleviate the gap between supply and demand. To successfully meet the objectives, we compiled all the available information for the study area, including the geology of the area, climatic parameters, land uses and availability of alternative water resources. Such information may contribute to the discussion for similar cases worldwide and provide the basic framework for approaching scientifically analogous problems.

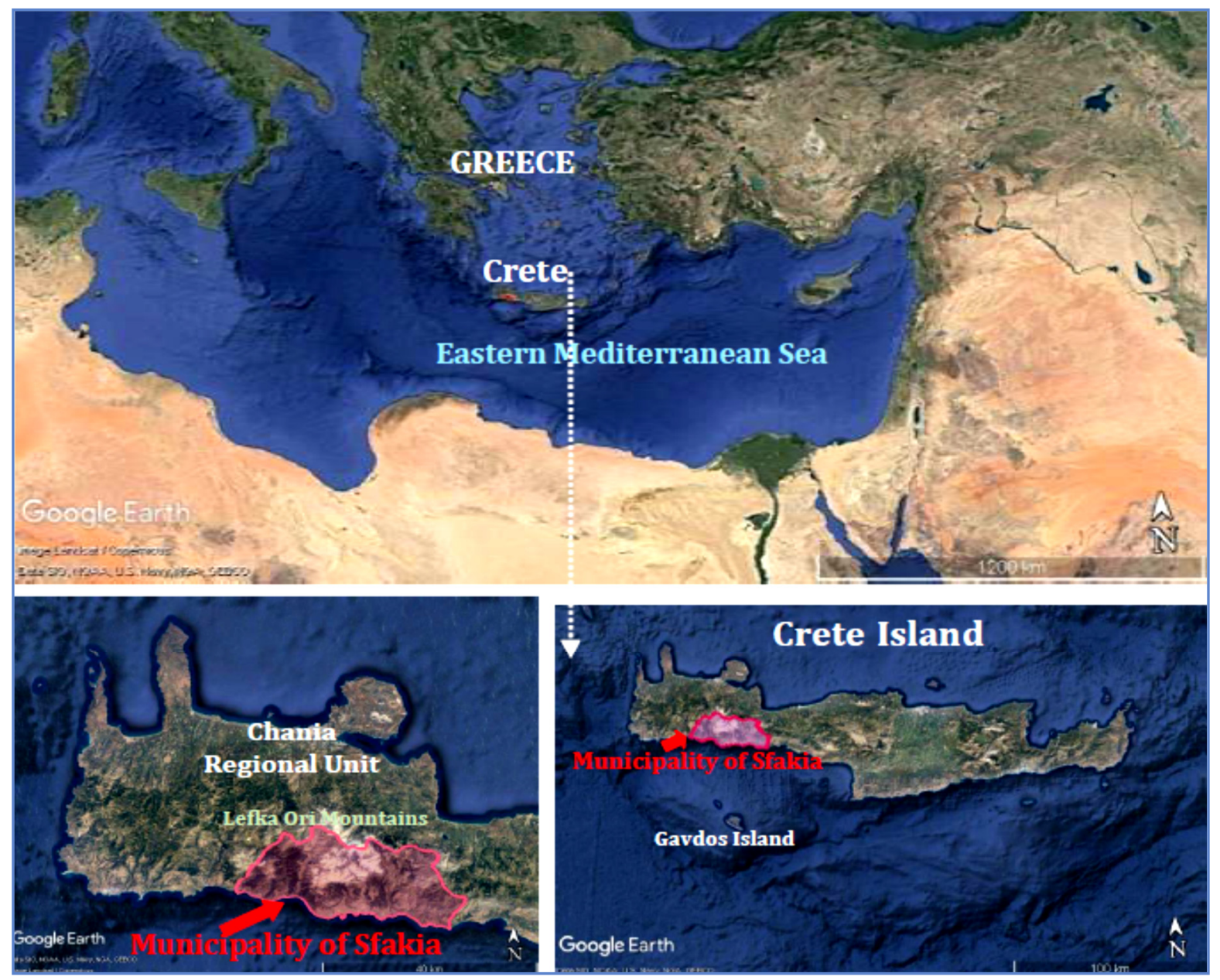

Figure 1. Representation of the study area's location on Google Earth maps. As it is indicated, the island of Crete is located in the middle of the Eastern Mediterranean Sea. The Sfakia Municipality region lies in the southwestern part of Crete, specifically in the southern part of the Chania Regional Unit, including a major part of the "Lefka Ori" Mountains. 


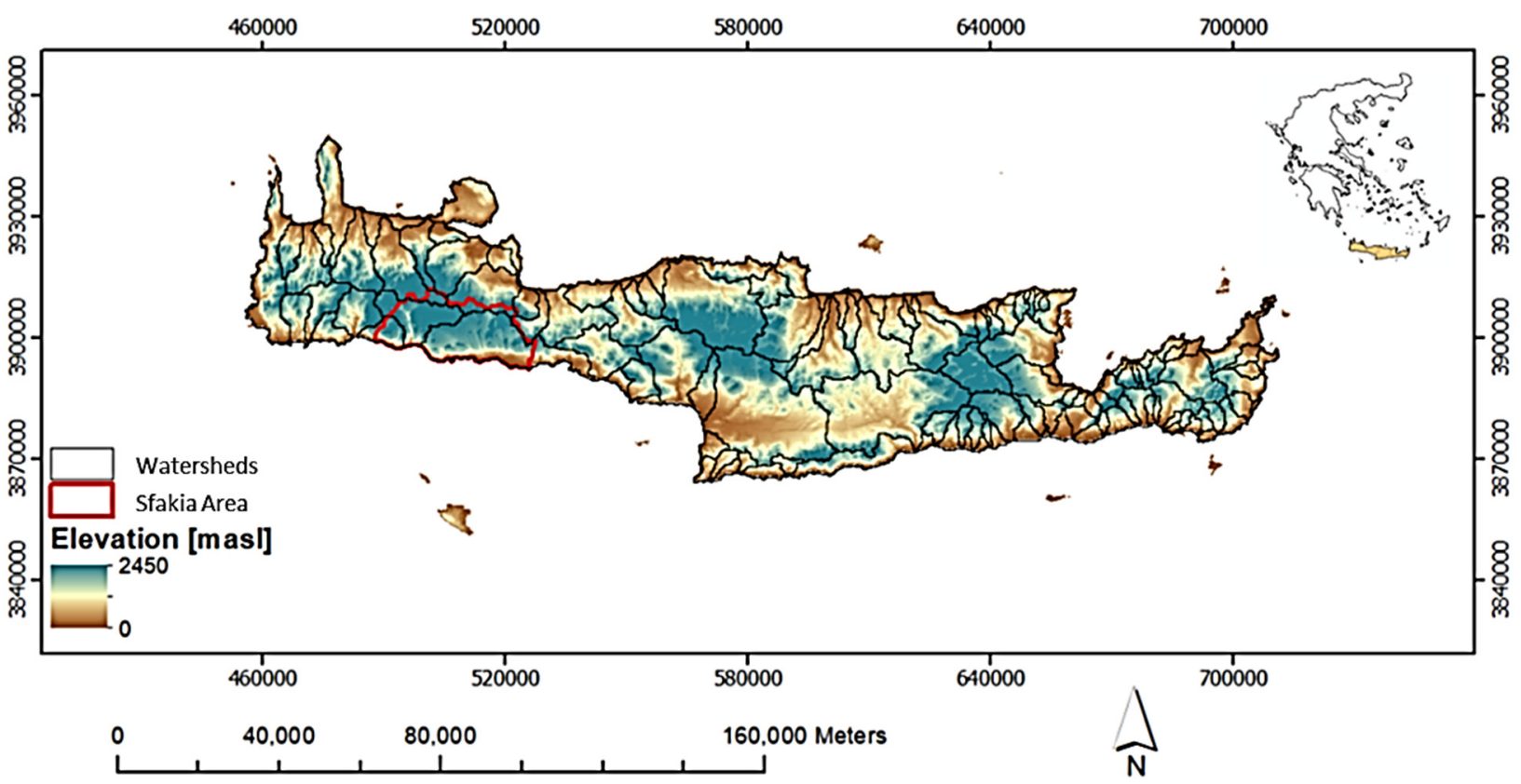

Figure 2. Location of Sfakia area and the elevation across the island of Crete.

\section{Methodology}

The study is based on the collection, processing and evaluation of primary and research data, as well as of the scientific data provided on satellite images, geothematic maps and bibliographic sources relevant to the object and the area of research. They also were evaluated, and we present the results derived from the qualitative and quantitative analysis of specific data regarding the climate, the geomorphology, the geology and the hydrogeology conditions. In addition, extensive research was carried out (on-site visits and interviews are included) to investigate the historical and current conditions on water-supply management, and they are presented in this study.

The climatic data used in the study were collected from four meteorological stations located in the area, all of them in high altitudes: the stations of Xyloskalo and Samaria gorge at the northwest part, the station of Askifou at the northeast and the Anopolis station at the south. The existence of meteorological records in both the eastern and western mountainous areas allows for a better depiction of the climatic conditions of these areas, even if the available time series are not extensive.

\section{Karstification and Highly Permeability of Geological Layers}

The basic properties of geological formations are karstification and, of course, the permeability and the availability of water resources. Permeability is the property or capacity of a porous rock, sediment or soil for transmitting a fluid without impairment of the medium; it is a measure of the relative ease of flow under unequal pressure. Intrinsic permeability is the permeability of rock independent of fluid properties (adapted from Reference [24]). Among climatic conditions and land use, local geology is highly affecting the water availability.

Limestone (marble) deposits are almost always in areas with very little silica-rich sedimentation, reflected in the relative purity of most limestones (Figure 3). Unlike clastic sedimentary rock, limestone is produced almost entirely from sediments originating at or near the place of deposition [25].

Karst is most strongly developed in dense carbonate rock, such as limestone, that is thinly bedded and highly fractured. Variations in porosity and permeability due to diagenetic processes in the paleokarst zones in several areas of the world. In some places it is shown that a tremendous amount of complicated diagenetic processes have had a great impact on both the porosity and permeability of the rock [26]. In addition, it is shown 
that porosity and permeability had no clear trends within the $12 \mathrm{~m}$ layer, and the highest porosity and permeability occurred in the deepest unit of the studied chalky dolostone.

Karst is not typically well developed in chalk, because chalk is highly porous rather than dense, so the flow of groundwater is not concentrated along fractures. Karst is also most strongly developed where the water table is relatively low, such as in uplands with entrenched valleys, and where rainfall is moderate to heavy. This contributes to rapid downward movement of groundwater, promoting dissolution of the bedrock, whereas standing groundwater becomes saturated with carbonate minerals and ceases to dissolve the bedrock [27].

The world's largest limestone karst is Australia's Nullarbor Plain. Slovenia has the world's highest risk of sinkholes, while the Western Highland Rim in the Eastern USA is at the second-highest risk of karst sinkholes. Moreover, in Canada, Wood Buffalo National Park, NWT contains areas of karst sinkholes [28]. Mexico hosts important karst regions in the Yucatán Peninsula and Chiapas.

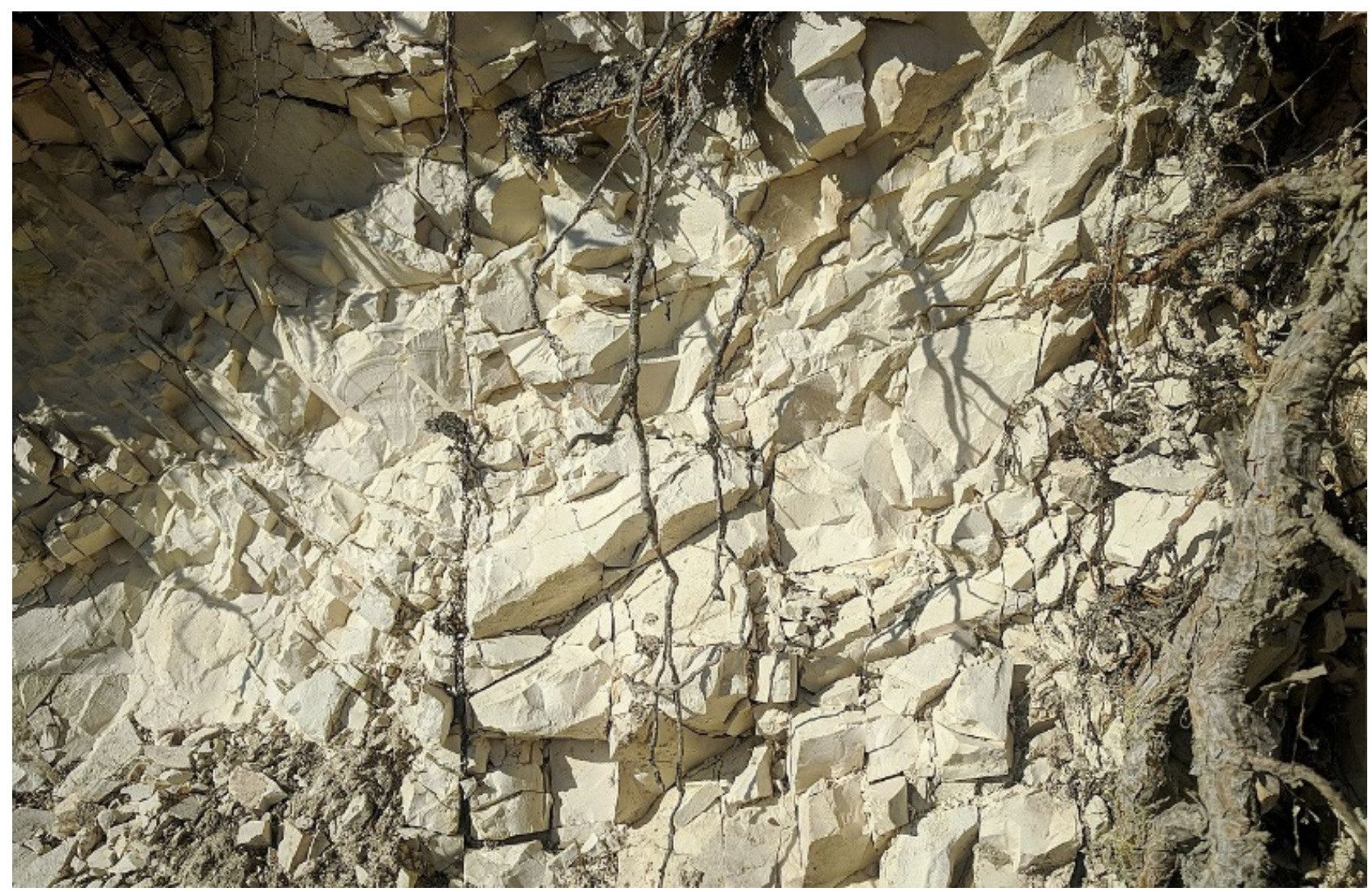

Figure 3. A limestone deposit in the Dinaric Alps near Sinj, Croatia [29].

A previous study [30] considered that karstification below the sea level in Lebanon and around the Mediterranean was developed during the Messinian crisis of salinity. It considers that the Messinian Crisis of Salinity (MCS), which is a major event which occurred 5.3 $\mathrm{M}$ years ago, allowed the development of valleys and karst very lowly below present sea-level. Ignored by hydrogeologists and karstologists until the 1990s, the MCS is now considered to be a major period for developing karst conduits at great depth below the present sea level. The littoral karst system in Lebanon, and its large submarine springs are taken as an example to show the functioning of such coastal aquifers.

Seawater intrusion into the littoral aquifers exists in many coastal areas of the world, particularly in karst regions. Freshwater quantities, which are, in this way, lost for human use, are significant. It is estimated that, in the Mediterranean coastal karst area, these amounts are approximately $25 \times 10^{9} \mathrm{~m}^{3}$ annually [31]. 
Another reason of water loss in Crete is deep karstification, which extends below the current sea level and this apparently can cause the direct discharge and loss of water. Deep boreholes in the Plattenkalk series at the western piedmonts of Dikti mountain in Crete revealed active karstification in elevations ranging from 60 to $150 \mathrm{~m}$ below the mean sea level [32].

Major problems with karst aquifers in Crete are sea intrusion and brackish ground water in littoral areas and direct discharge of groundwater below the sea level in continental regions. The latter seems to be related to the ways of facing scarcity of water resources in karst places under high atmospheric precipitation. A recent overview of karst system research in Greece is provided by Reference [33] and tested the application of geophysical methods in combination with pumping tests that provide a cost-effective and efficient alternative to estimate aquifer parameters. A recent study provided valuable guidance on predicting the groundwater reserves in aquifers with a similar hydrogeological regime [34]. This is a possible explanation for littoral aquifers; however, in the case of inland mountains, such as Lefka Ori, Lasithi Plateau and Sfakia, deep kartification and high permeability could be due to the sea level lowering by 130 to $150 \mathrm{~m}$ during repeated glacial periods in the Quaternary.

\section{Physical Settings}

\subsection{Climate}

Crete, Greece, is classified as being in the temperate climate zone between Csa (the Mediterranean hot summer climate) and Csb (the Mediterranean warm/cool summer climates), according to the Koppen climate classification. Crete can be subdivided into several climatic types. In the coastal zones, the climate is typical Mediterranean with varying hygrometric and temperature characteristics from the west to the east, and north and south, while, at the higher altitude zones, it is classified as having a continentalmountainous climate type.

The average annual precipitation in the broader Sfakia area increases roughly linearly from 350 to $400 \mathrm{~mm}$ at the coastal areas to more than $2000 \mathrm{~mm}$ at the higher watershed regions, with an average precipitation gradient of about $70 \mathrm{~mm}$ per one hundred meters of elevation. According to the recent drought analysis for the island of Crete included in the river-basin management report for the water sector of Crete the hydrological balance of the study area $\left(481,645,348 \mathrm{~m}^{2}\right)$ consists of average rainfall $1851 \mathrm{~mm} /$ year, pumping $710,030 \mathrm{~m}^{3} /$ year and recharge of $481,423,791 \mathrm{~m}^{3} /$ year. The recharge coefficient has been estimated equal to $54 \%$, due to the karstic nature of the geological relief. The remainder is mainly lost to evapotranspiration, while surface runoff is negligible (CMD, 2017).

The average annual precipitation of the island of Crete is averaged to $969 \mathrm{~mm}$ [23]. The temporal rainfall variability in Crete has remained almost stable, without any significant change in the last 40 years $[35,36]$. The number of rainy days, however, has decreased compared to the early 1980s, while rainfall intensity has increased [36].

The Municipality of Sfakia has an extensive south windward coastal land zone, a south windward mountainous zone and a distinct mountainous zone which can be characterized as a north windward zone due to snowfall in the area from northern cold currents. Because the maintenance of the snow cover, which remains until the summer months in the peaks of Madara, the north windward zone could be classified as an Alpine climatic zone. The climatic zones of Municipality of Sfakia maintain common features, but, at the same time, they show great differences. A common feature is the periodicity in climatic phenomena, attributed to a Mediterranean climate, including mild winters and warm-dry summers, particularly in the mountainous and coastal zones. In regard to climatic variability, ascribed to the intense geomorphology of Sfakia area, the region can be divided into three different zones. In the first zone, low-lying coastal areas are included, while the western mountainous part, with a boundary separating it from Chora (city) of Sfakia and further west (including the Samaria Gorge), is the second one. The third zone includes the eastern mountainous 
part, east of Chora of Sfakia. The most important differences in the imprint of the climatic conditions in these zones can be summarized as follows:

(a) The annual duration of sunshine is longer in the coastal zone compared to the mountainous zones, where the average annual sunshine is limited by cloud formation that is favored by the surrounding geomorphology.

(b) The temperature variations are milder in coastal zone compared to mountainous areas (temperature difference between day and night). From October to April, lower temperature values are recorded in the eastern mountainous area, due to the northerly currents, which explain the more frequent snowing and frost, particularly early in the morning.

(c) The humidity factor also differs between the three zones, due mainly to variations in the altitude. The coastal zones show higher hygrometric conditions compared to mountainous areas, which is ascribed to sea proximity, but, again, the hygrometric conditions of the southern coastal areas are higher than those of the northern coastal areas. An important role in the differentiation hydrometric conditions is the frequent appearance of the north currents ("Meltemi"), especially during the summer period.

(d) Both mountainous areas show higher rainfall and snowfall compared to the eastern mountainous areas. The low coastal zones do not have high rainfall, and there are a number of surface streams-gorges that are reflected throughout the southern front of the municipality.

All areas of the municipality show similarities in terms of wind intensity. An exception, with annual periodicity, is the eastern coastal zone where the north current operates more intensively with downward wind conditions, due to the geomorphology of the area, showing long intervals with strong wind intensities. Additionally, in the same area, again, due to special geomorphology, a strong descending wind is created which is caused in combination with the breeze causing great intensity of the winds in the night and early morning hours mainly from June to September. In the coastal land zone of the Sfakia area, the average annual number of hours of sunshine is around $3000 \mathrm{~h}$ in the western areas, while up to $3100 \mathrm{~h}$ of sunshine have been recorded in the eastern areas of the municipality. The coldest months are January and February, with an average temperature of approximately $13{ }^{\circ} \mathrm{C}$, while the months with the highest average temperature are July and August, with an average temperature of $28^{\circ} \mathrm{C}$. January is the month with the highest rainfall, with an average of $82 \mathrm{~mm}$, while the average annual rainfall is just over $320 \mathrm{~mm}$ (Figure 4). In the eastern mountainous area of the Sfakia Municipality, the average annual number of hours of sunshine is close to $2700 \mathrm{~h}$. January is the coldest month, with an average temperature of $7{ }^{\circ} \mathrm{C}$. Despite the high altitude of this mountainous area, the temperature rarely drops below $0{ }^{\circ} \mathrm{C}$, and this happens mostly in January and less frequently in February. July and August are the warmest months, with an average temperature of $23^{\circ} \mathrm{C}$ (Figure 4a).

A large difference is observed in the rainfall data of the western mountainous zones (Figure $4 \mathrm{~b}$ ), with the average precipitation height at $712 \mathrm{~mm}$ for the plateau of Anopolis, while at the entrance of the Samaria Gorge, in Xyloskalo, the average annual precipitation is $1601 \mathrm{~mm}$. Respectively, in the old settlement of Samaria, an annual average of $1396 \mathrm{~mm}$ is recorded. Snowfall during the winter season is common even up to the settlements of Anopolis plateau in a smaller thickness of snow. In the higher latitudes, the annual snowfall is remarkable.

The eastern mountain zone of Sfakia is a hydrological basin, which gathers one of the highest rainfall figures in Greece. Indeed, the average annual precipitation reaches $2160 \mathrm{~mm}$, while there are also years with the annual precipitation reaching or even exceeding $3000 \mathrm{~mm}$ (winter of 2001/2002 with $3146 \mathrm{~mm}$, sum up of the years). Snowfalls occur on an annual basis with significant amounts of snow remaining for a long time in the surrounding mountainous areas. The coldest month is January, with an average monthly temperature of $6{ }^{\circ} \mathrm{C}$, but temperatures below $0{ }^{\circ} \mathrm{C}$ are very common in January and February. Despite the high precipitation, the average annual sunshine in this zone reaches $2700 \mathrm{~h}$ on average. 


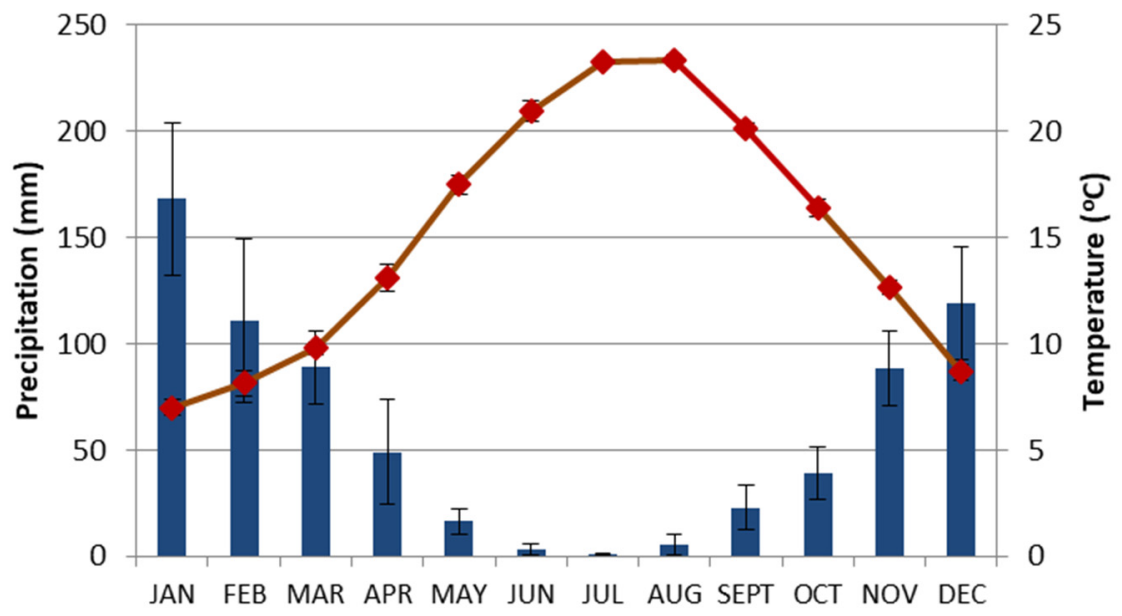

Month

(a)

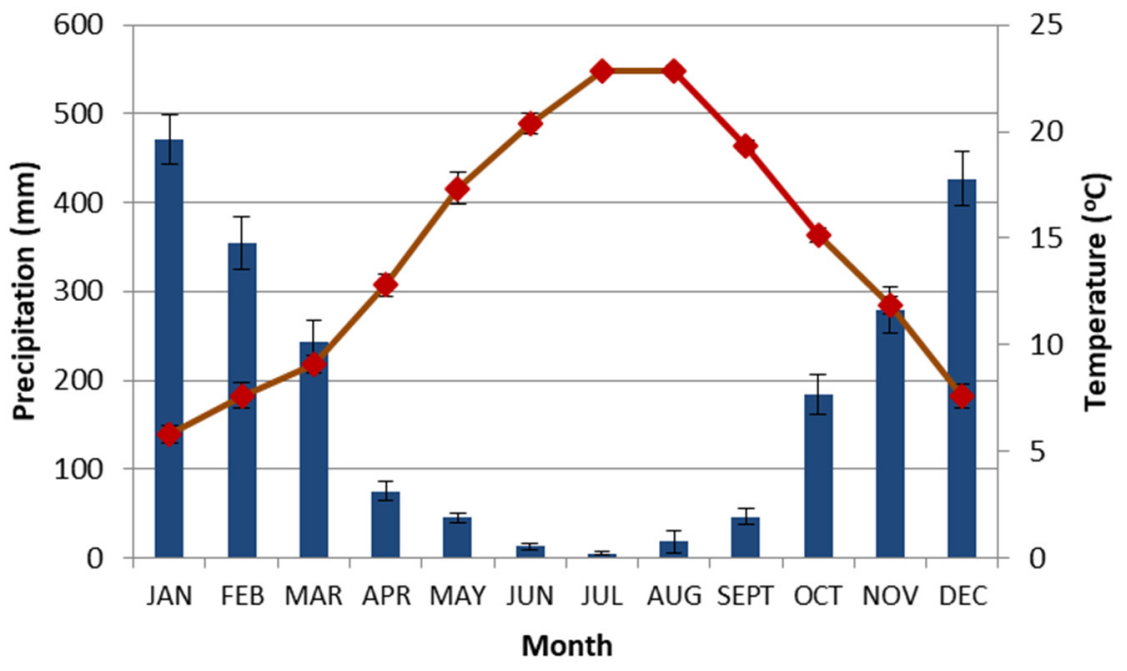

(b)

Figure 4. Average monthly precipitation and temperature in (a) the west and (b) the east mountainous areas of the Municipality of Sfakia. Data were collected from Xyloskalo, Samaria gorge, Askifou and Anopolis stations for the period from 1981 to 2020.

4.2. Geology

\subsubsection{Geomorphology}

The Sfakia investigated area is characterized by a wide variety of geomorphological features, such as snow-covered peaks, plateaus, gorges and caves, as well as many types of karstic formations, both on the surface and underground. Karst erosion in the carbonate rocks has contributed to the creation of a remarkable diversity of karst forms, including large karst caves and deep sinkholes [18-20,22,37].

In the context of this study, the Morphological Map of the Sfakia Municipality region was formed and is presented in Figure 5. As shown on the map, the altitudes are ranging from $0 \mathrm{~m}$ along the coastline located in the southern part of the municipality to $+2454 \mathrm{~m}$ at the peak of "Lefka Ori" Mountains. A great number of peaks, all above the $+2000 \mathrm{~m}$ mark, dominate the "Lefka Ori" Mountains; "Pahnes" +2454 m, "Troharis" +2401 m, "Svourihti" +2337 m, "Agio Pnevma" +2254 m, "Kastro" +2218 m, "Fanari" +2170 m. Many plateaus 
have been formed as well, which are indicated on Figure 6, such those of Askifou, Tavri, Niato, Kallikratis and Anopolis.

The gorges cross the area with predominant directions N-S, such as the Samaria Gorge, Aradena Gorge and Imbros Gorge, along with many smaller ones. Along the steep coastline, limited beaches have been formed, some of which are not easily accessible.

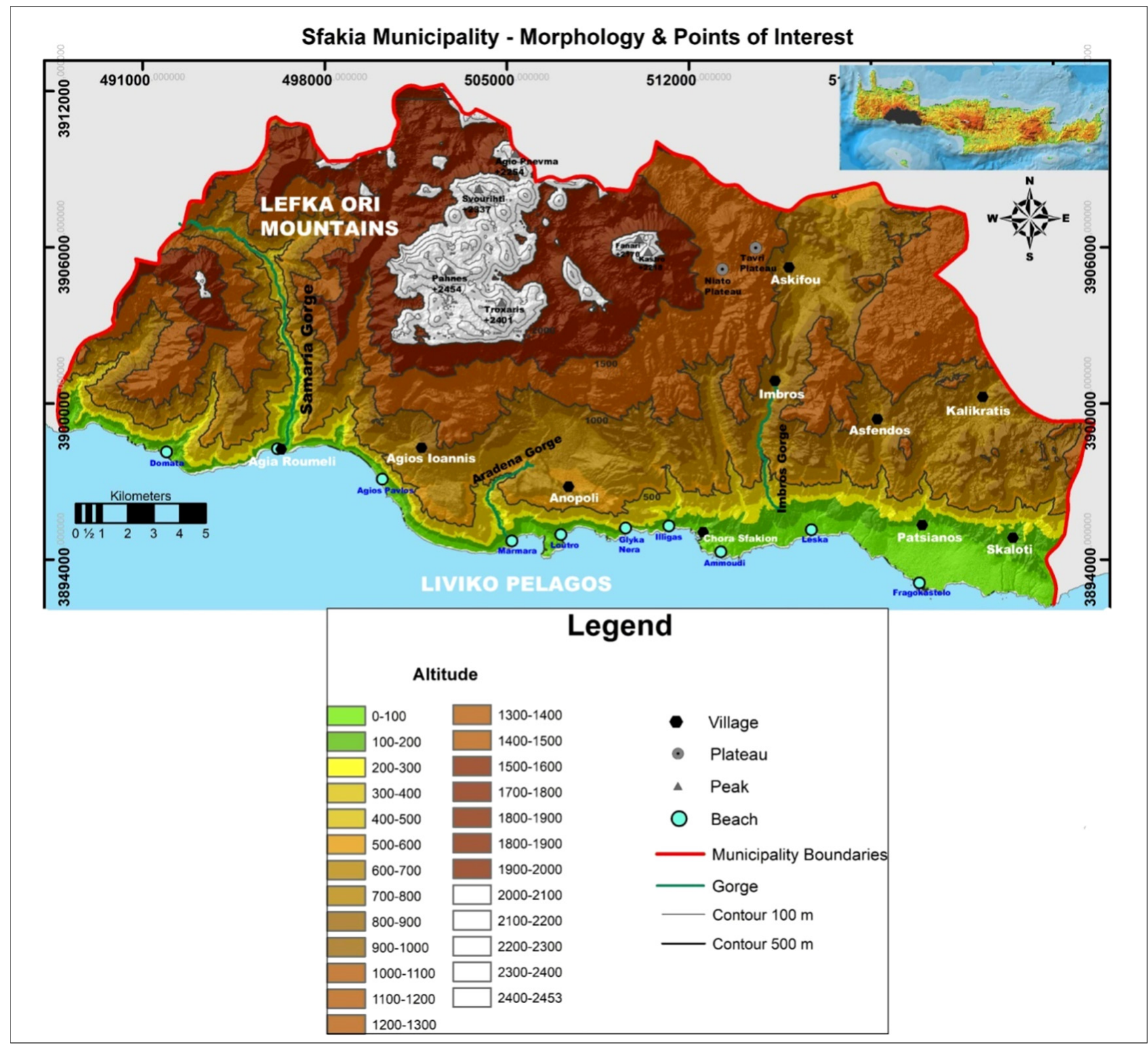

Figure 5. Sfakia Municipality morphological map. The map was formed in the context of this study. The altitude zones are represented in different colors, as symbolized in the legend. They range from 0 in the coastal zone to the highest altitude of $+2,454 \mathrm{~m}$ in the highest peak "Pachnes" of the "Lefka Ori" Mountains. The main morphological features, such as major peaks, gorges, plateaus and seaside points of interest, are depicted as well. 


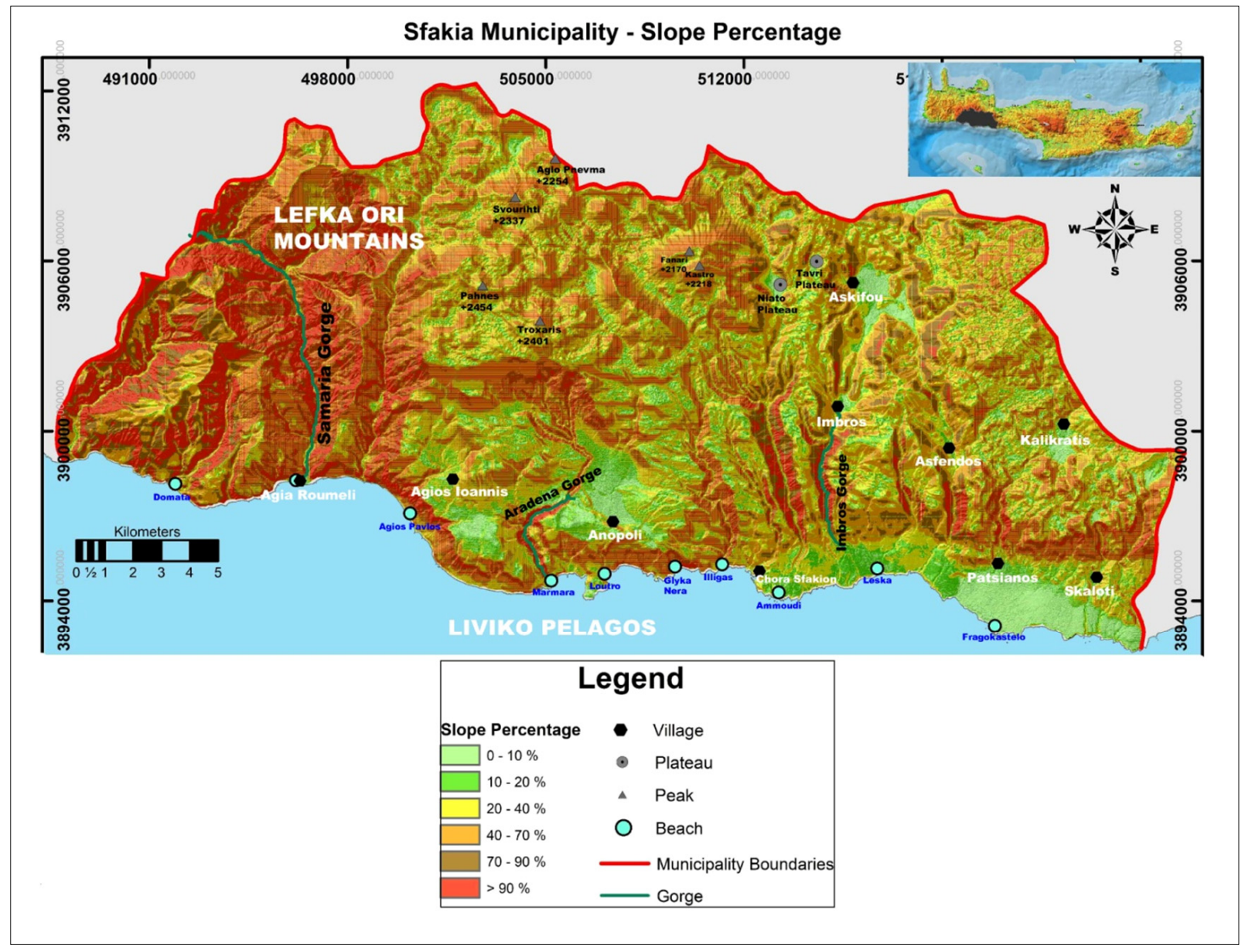

Figure 6. Percentage slope map of the Sfakia Municipality. The map was formed in the frame of this study and highlights the steep terrain that dominates the area, especially in the western part, and along the big gorges as well.

The terrain of the area is mountainous with steep slopes. In the frame of this study and, in particular, for the quantitative analysis of the percentage slopes distribution, the relevant map was formed and is presented in Figure 6. The slope-map assessment shows that a large part of the investigated region has steep slopes, steeper in the western part, especially along the large gorges, while only a small part of the terrain is gentle, particularly in the area of the plateaus and of Frangokastello basin as well (Figure 6). It is important to note that the steep terrain is one of the major causes which adversely affect the water transportation.

\subsubsection{The Geological Structure of the Sfakia—_Lefka Ori” Mountains Area}

In the frame of this study and in order to understanding the hydrogeological conditions, a significant importance was given to the deep knowledge of the geological ones which have a direct influence on the surface and underground water flows.

The "Lefka Ori" Mountains, as with the rest of the island of Crete, present a complicated geology, which has emerged from the extensive geological processes which were evolved in the wider area throughout a long geological history. The intense endogenous forces in interaction with the exogenous factors and especially that of erosion have influenced the creation of a remarkable geodiversity: karstic mountain landscapes, gorges, caves, sinkholes, etc. [19].

The geological structure has been formed progressively under the influence of the tectonic events, especially of the stress fields which have been evolved within the geodynamic evolution of the wider area, closely connected to the Alpine orogenesis, as well as to the 
geodynamic regime represented by the Eurasian and African plates' convergence and the southward migration of the convergence's limit since Miocene [18,38-40].

According to the scientific results derived from extensive research [17-19,21,37-39,41], the geological structure of the surrounding area is represented as a tectonic pile that consists of tectonic nappes, which were emplaced successively on top of each other, within the Alpine orogenesis, under a compression regime, closely connected to the plates' convergence. The southward migration of the convergence's limit affected the subsequent extension in Crete area which has had an impact on the uplifting and the extensional exhumation of the lower tectonic nappes consisted of carbonate rocks in the form of the "Lefka Ori" tectonic window [18,19,37]. All of these geological processes have contributed to the formation of the "Lefka Ori" Mountains as a huge carbonaceous mass bounded by significant faults, while various tectonic discontinuities cross its entire massif $[18,19,37]$.

According to Reference [18], the main tectonic stages that have influenced the geological structure of the "Lefka Ori" Mountains' (Figure 7) focus on the following:

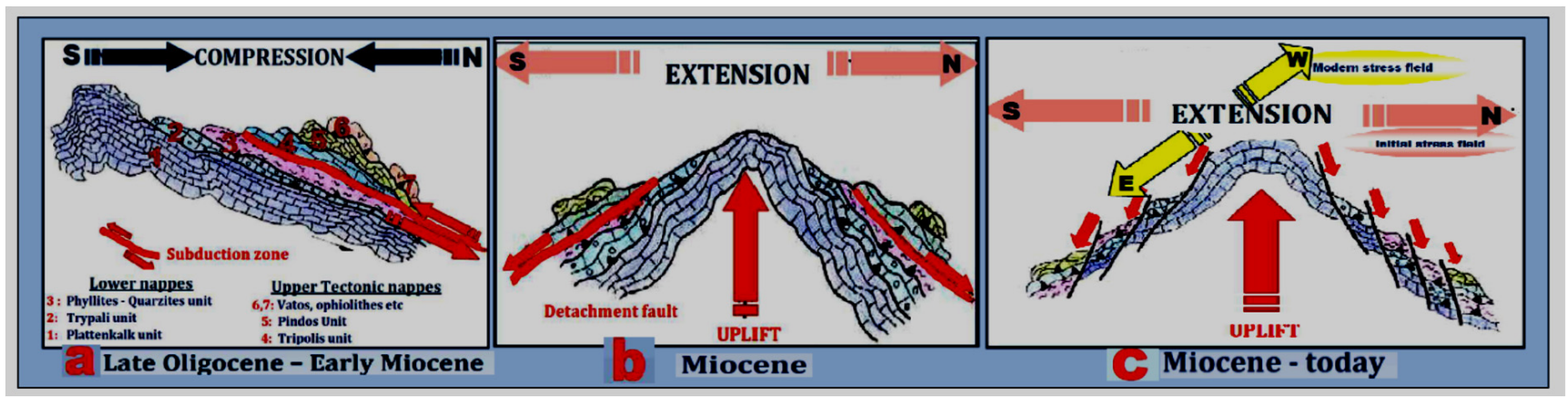

Figure 7. Development of the "Lefka Ori" Mountains' geological structure, under the corresponding stress fields (stages $\mathbf{a}-\mathbf{c}$ ), which were developed within the geodynamic evolution of the wider area, as analyzed in the text $[18,19]$.

During the period of Late Oligocene-Early Miocene, the configuration of the convergence's boundary in the wider Crete area caused the culmination of an N-S compression's regime (Figure 7a). This affected the extensive thrusts' evolution, which was completed with the immersion of the lower nappes as a slab that included the Plattenkalk unit (Pk), the Tripalion unit (Trip) and the Phyllites-Quartzites unit (Ph), beneath the upper plate with the upper nappes of Tripolis and Pindos (Figure 7a) [18,21,41-44].

Within the Miocene, the southward migration of the convergent boundary from the region of Crete to the Eastern Mediterranean's middle zone led to the development of an N$\mathrm{S}$ extension regime (in Crete region) (Figure $\mathrm{7b}$ ), while, at Pliocene-Pleistocene (Figure 7c), the direction changed to the E-W extension (Figure $7 \mathrm{c}$ ) $[17,18,41]$. The wide extension, in combination with the pushing of the the subducting African plate beneath Crete had contributed to the strong tectonic uplift and to the exhumation of the lower nappes on the form of the "Lefka Ori" tectonic window [18] (Figure 7c). This operation was accompanied by the creation of successive normal faults series, which constitute, today, the borders of the "Lefka Ori" Mountains and the tectonic basins, where the Neocene and Quaternary sediments have deposited from Miocene until now [18].

According to the most prevailing views, the "Lefka Ori" Mountains (Figure 8a) constitute a huge tectonic window of the uncovered lower tectonic nappes, in particular, of "Plattenkalk unit" (Triassic-Eocene), mainly consisting of carbonate rocks [17-19,37,41]. 

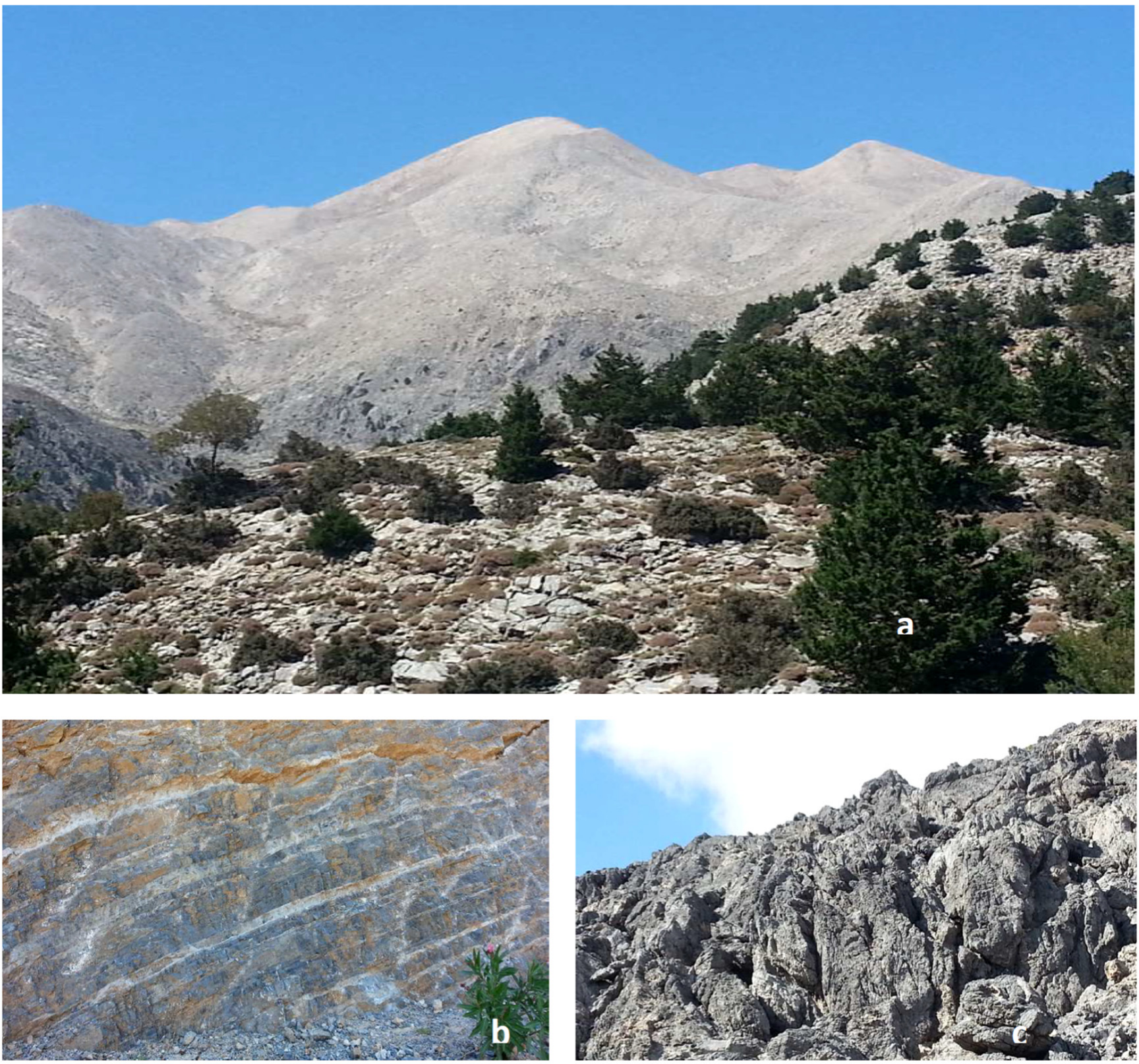

Figure 8. "Lefka Ori" Mountains: (a) Landscape; it consists of carbonate rocks (b) "Plattenkalk unit"; well bedded, gray-bluelimestone (marbles) including thin intercalations of white cherts, and (c) "Trypalion unit"; unbedded and strong tectonized limestone and dolomite. These geological features in combination with the high precipitation, contribute to the intense karst development (photos by Aik. P. Pavlaki).

The "Plattenkalk unit" (Pk, Triassic-Eocene; Figure 8b) appears to be formed by the development of well bedded, gray-blue recrystallized limestones (marbles), including white or black cherts, under the form of thin intercalations and bulbs $[21,45]$. Typical appearances of the above layers can be found in the southern part of the Samaria gorge, as well as in the Imbros gorge. The upper layers progressively have been evolved to thick-bedded marbles with intercalations of ash-greenish calcitic phyllite, passing on the top in a flysch. Flysch, as was identified by References [18,46] and named "Lefka Ori-Plattenkalk metaflysch", consists of slight metamorphism's calcareous and chloritic phyllite and is characterized by thin developments and rare appearances. 
The deep underlying layers' system is mainly consisting of thick bedded or even unbedded white-gray marbles, of stromatolithes, as well as of dark gray-black dolomites (Figure 9), which are observed in the higher mountain region, as well as in the central and southeastern part of the study area [37]. These geological formations (dolomites) are of the outmost hydrogeological importance, due to their widely karstification, which has given rise to various karstic formations, as caves and karstic potholes that contribute to the high water percolation rate.

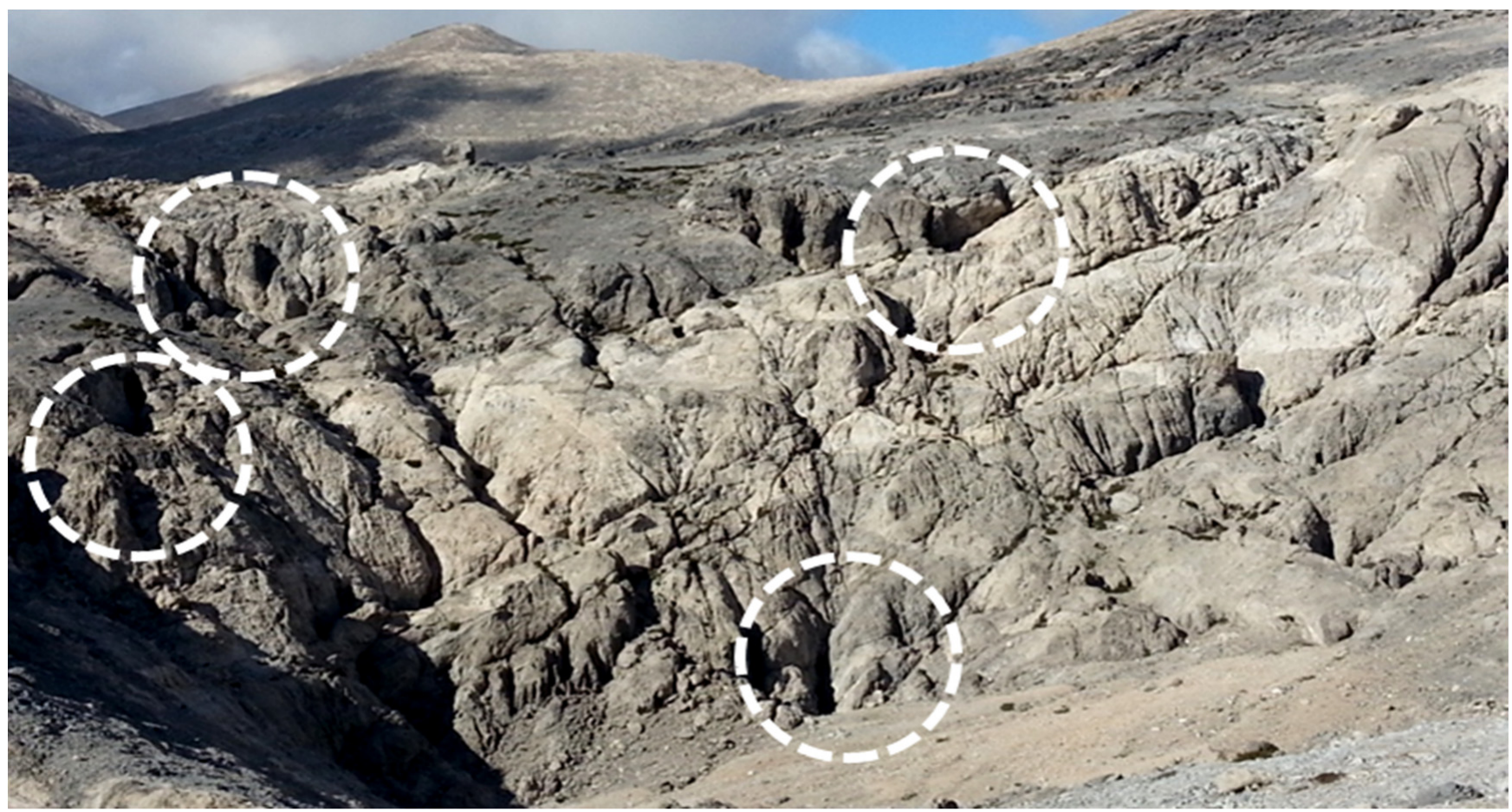

Figure 9. Karst landscape which dominates in the Central "Lefka Ori" Mountains' area at altitudes +2000 m. It consists of black and dark gray dolomites. As was proven by References [14,37], these geological formations present an enormous karstification, which contributes to the creation of a wide variety of karst structures, namely dolines, caves and karst potholes, through which all the melted snow and rainwater penetrates, enriching the underground aquifers (photo by Pavlaki Aik.).

Regarding the underlying "Plattenkalk" system, there have also been recorded local appearances of low metamorphic layers, mainly consisting of yellowish-white clays, gypsum, brown schist, as well as of well bedded crystalline limestone [21,45].

The "Tripalion unit" (Trip, Triassic-later) is clearly thrusting on the "Plattenkalk unit", and it consists of carbonate rocks (Figure 8c). It presents two different and distinct lithophases which led to their corresponding division into the lower layers and the medium-upper ones $[18,19,37,46]$.

The lower layers are similar to those of "Plattenkalk unit", and they consist of wellbedded gleaming white-gray marbles, with the difference being that they have not included cherts. These layers evolved through lateral lithophases' transitions to the medium-upper and strong tectonized layers, which consist of thick bedded to unbedded crystalline carbonate rocks. They include white limestone and black dolomite (Figure 8c), as well as black cellular dolomite and carbonate breccia-conglomerate, the pebbles' and breccias' of which originate from the geological formations of the "Plattenkalk unit" and its underling system [18].

Finally, in the plateaus' areas and in the southern region, especially in the Fragokastello area, the Neocene and Quaternary sediments have been deposited from Pliocene, including marls, conglomerate, sandstone, lays and sands. 


\subsubsection{Permeability and Infiltration}

In the northern part of the "Lefka Ori" Mountains, which is the adjacent to the Sfakia area, where similar geological conditions prevail, extensive research and studies have been carried out, leading to the identification of important underground karstic aquifers, the water of which is currently exploited [12]. Based on the above research data, the values of the water permeability coefficient, $\mathrm{K}$, regarding the Trypalion unit carbonate rocks, were calculated in a range of $10^{-3}<\mathrm{K}<10^{-2} \mathrm{~m} / \mathrm{s}$. According to the results of those hydrogeological research studies, the locations of wells for pumping groundwater were determined and carried out in the karstic aquifer of Agyia-Lefka Ori at the site of Myloniana (northern "Lefka Ori" Mountains) with absolute success, characterized by an excellent operational capacity of $1300 \mathrm{~m}^{3} / \mathrm{h}[14,47,48]$.

Taking into consideration all the geological factors mentioned in the last paragraphs, it is believed that, in the wider Sfakia area, the interaction of the geo factors relative to the geological formations, represented by the hydropermeable carbonate rocks and the intense tectonic, which is characterized by the significant discontinuities development, in combination with the climatic conditions as well, contributes to the water infiltration and to the underground karstic aquifers' formation. In the mountainous karstic area, the average annual infiltration is estimated to be over $45 \%$ of the total annual precipitation.

\subsubsection{Overview of Land Cover, Soil Types and Hydrogeology}

An overview of categorized land uses, including cropland, scrubs, forests, mountains and urban areas in the Sfakia area, is given in Figure 10a. The area has limited agricultural land, while forests, scrubs and herbaceous vegetation cover the majority of the land surface (Figure 10a). Thus, raising livestock is the major activity in the area. The soil types are divided in four main categories and are affected by the area's geological characteristics (Figure 10b).

The Sfakia Municipality includes three distinct hydrological basins and an extended network of streams, mainly ephemeral. From a hydrogeological point of view, the Sfakia area is covered mainly by the karst formations, as mentioned above, with limited areas of porous medium formations mostly at its eastern part (Figure 10c).

As was proven from Pavlakis (1989, 1999 and 2014) [14,49], and according the results derived from extensive research and hydrogeological studies [13,18,47,48,50-54], a remarkable underground karstic aquifer system has been revealed in the surrounding "Lefka Ori" Mountains' area. It was found that the geological structure of the "Lefka Ori" Mountains, which consist of tectonized carbonated rocks, influences the formation of a compound underground aquifer system in which the development of faults of great length has caused its subdivision into individual aquifers [14]. In addition, faults functioning as barriers to the groundwater flow have been identified, as well as those which function as aqueducts $[14,18,19,48,50]$. Under the interaction of the hydrogeological and climatic conditions, the highest percentages of the rainwater falling on the "Lefka Ori" Mountains, as well as that produced from snow melting percolates through the limestone masses and flows down to the shores. Part of the groundwater flowing to the northern and to the southern shores emerges very close to the sea and the water is brackish. The remaining groundwater, during its flow to the north, encounters impervious layers before reaching the coast and forms large sources of fresh water in the areas outside the Sfakia area (Agyia, Stylos-Armeni, Kourna lake, etc.), with an average annual discharge of 350 million $\mathrm{m}^{3}[14,15]$. 

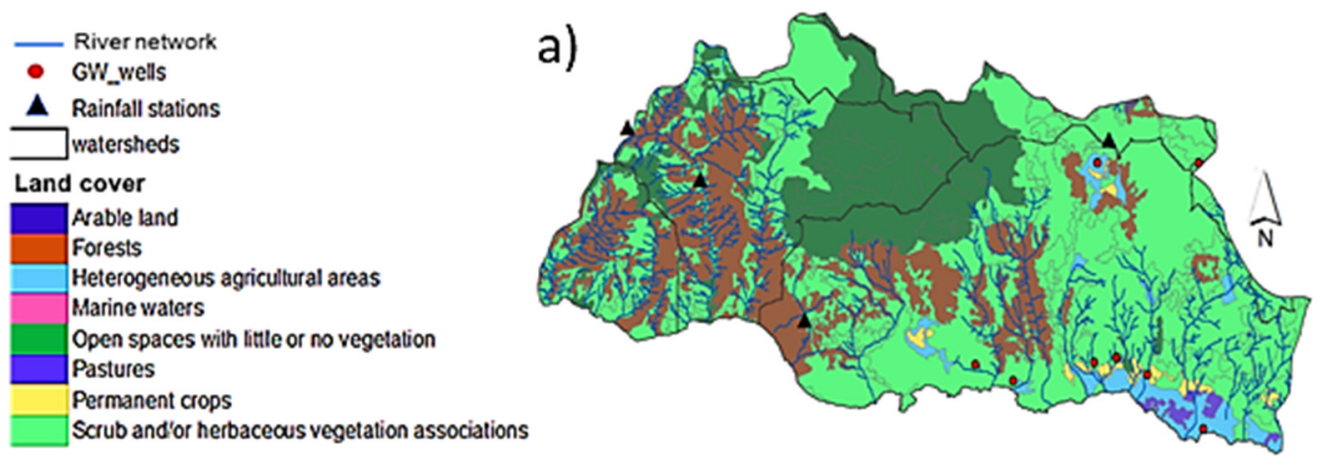

watersheds.
Soil type
\begin{tabular}{|l} 
Allotigenic orphans Alkaline Mediterranea \\
Alpine humus RANKER type \\
Limestone Retzines \\
Limestone Retzines with impurities \\
Podzolic acidic forest soils
\end{tabular}
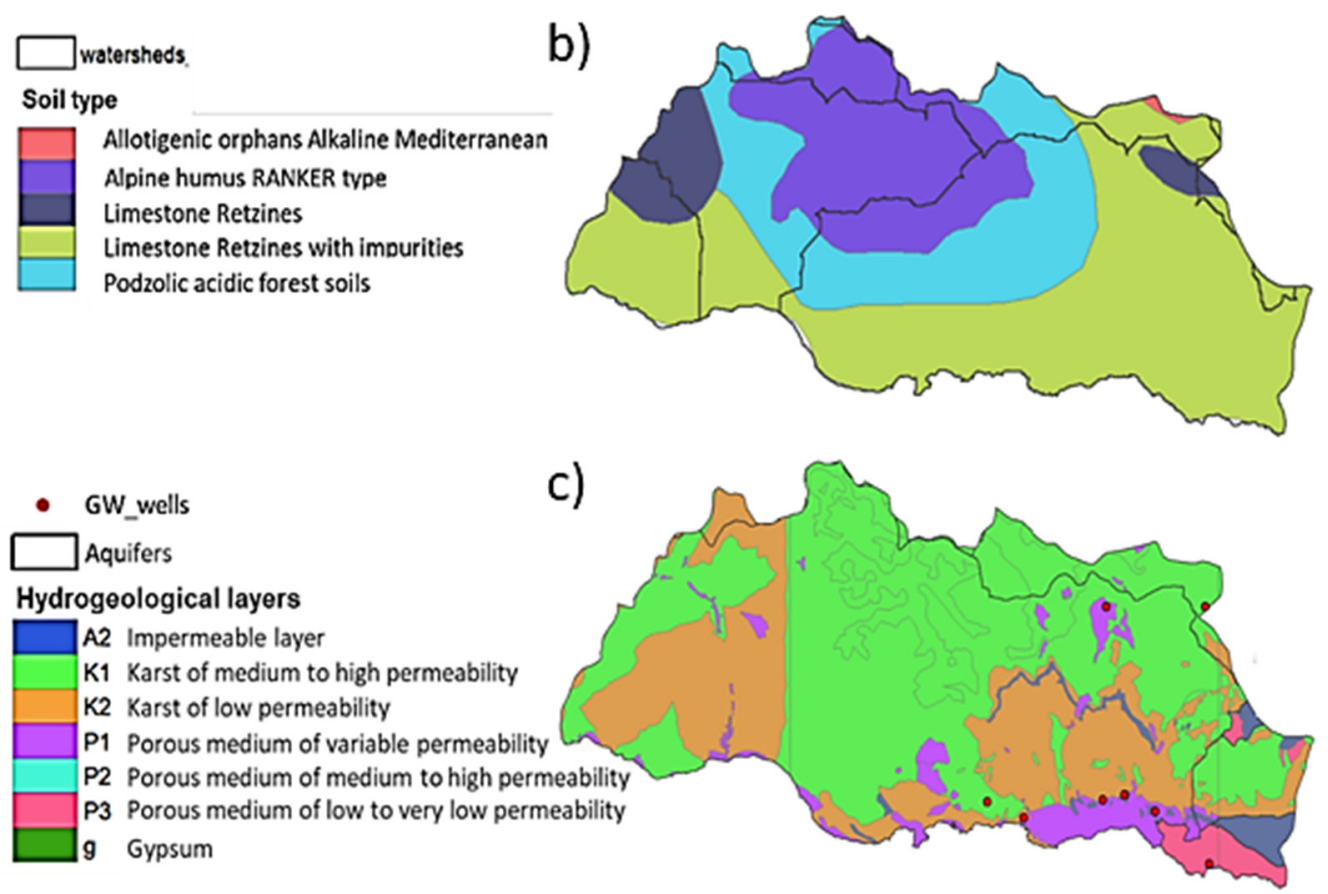

Figure 10. Land cover (a), soil types (b) and hydrological layers (c) in of the Municipality of Sfakia.

\section{Historical Information of Water Supply}

Sfakia has been facing water-supply problems since its inhabitation. This fact is attributed to the combined effect of several factors, including the relief of the mountainous area, the spatial variability of climatic conditions and the geology of the area. Historically, in the area, where natural plateaus and underlying aquifers are created (e.g., Askyfou, Anopolis and Kallikratis), the supply of water was based on the groundwater, and, in settlements located at high elevations (e.g., Asfentou, Kallikratis, Imbros, Agios Ioannis and Aradena), the water supply was based on rainwater harvesting and storage in cisterns (rain tanks). Additionally, surface water sources and natural springs, even with small supplies, existed only in settlements at low altitudes (Patsianos, Kapsodasos, Frangokastello, Skaloti, Argoules, Agia Roumeli and Chora). Remarkable exceptions are the two or three small springs in the Kallikratis settlement. The water supply of the Agia Roumeli is also based on springs of the gorge of Samaria.

Briefly, the remnants of water harvesting and storage constructs which are found throughout the Sfakia area are indicative of the water scarcity that encountered the region during the summer time. These constructs are dated in the Roman, Byzantine and Venetian (Koule Kaba) times. Examples are as follows:

(a) LC of Askyfou: In June 1867, in Askyfou, a battle took place between Ottomans under Mehmet Pasha and the Sfakians. The Sfakians repulsed and trapped the Turks in 
Kares, until Resit Pasha came to their aid. Due to the heat and the lack of water, they were forced to leave Askyfou [55].

The plateau of Askyfou is very fertile and played an important role for feeding and water supply of community through the centuries since the Byzantine times (Figure 11). The Askyfou habitants constructed wells of 10-15 m for pumping ground water. Such a well is located in Mile, southeast of the village, and was used as a water supply until the middle of the last century; it is shown in Figure 11b.

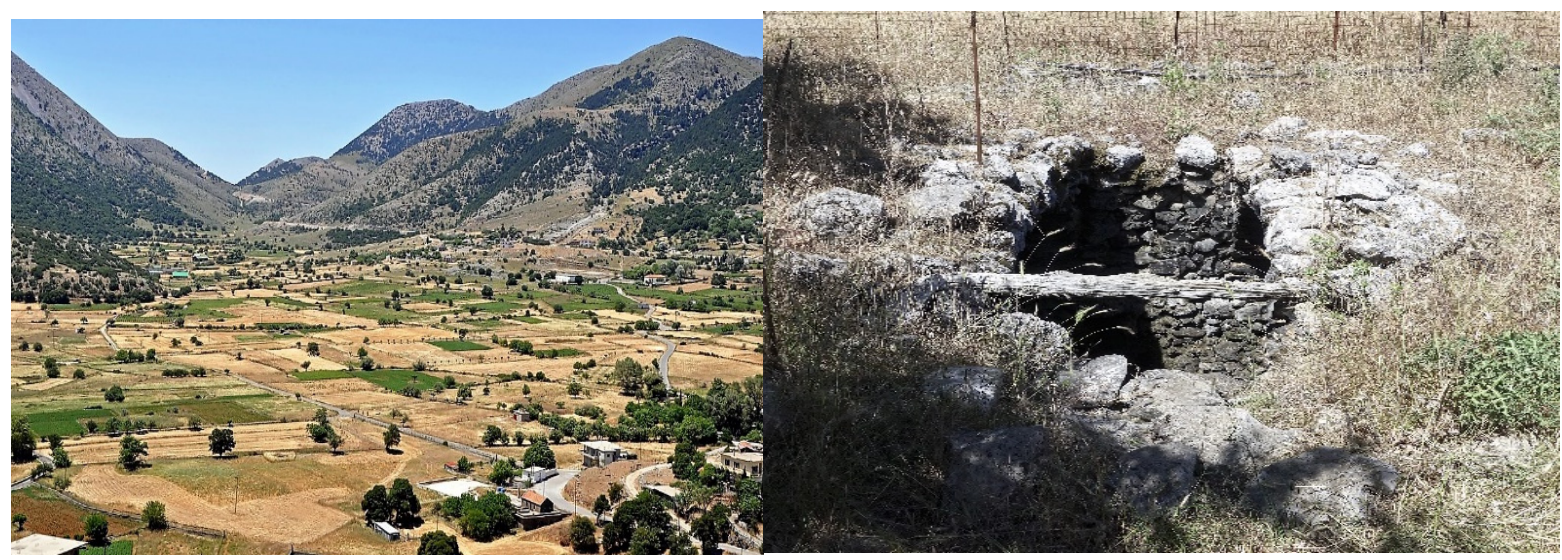

(a)

(b)

Figure 11. Askyfou: (a) plateau and (b) an ancient well in Askyfou (photos by A. N. Angelakis).

(b) LC of Anopolis: Anopolis is located in the synonymous plateau $13 \mathrm{~km}$ west of Chora, Sfakia. It is a small plateau formed below the Sfakiani Madara, which is considered to be one of the most inaccessible provinces in Europe. In the place of the present village of Anopolis was built the ancient city, which has been there since the Venetian time.

The ancient city flourished during the Roman, Byzantine and Venetian times. Remains of the city, including those of a water cistern on the hill of Agia Aikaterini, are preserved. It was used for rainwater harvesting and storage. The same water-supply technology was used by the Venetians, who increased the scale of the cisterns. Such a Venetian cistern located in Koule Kaba place northeastern of the village is shown in Figure 12a. This cistern is still in use mainly for watering sheep and goats.

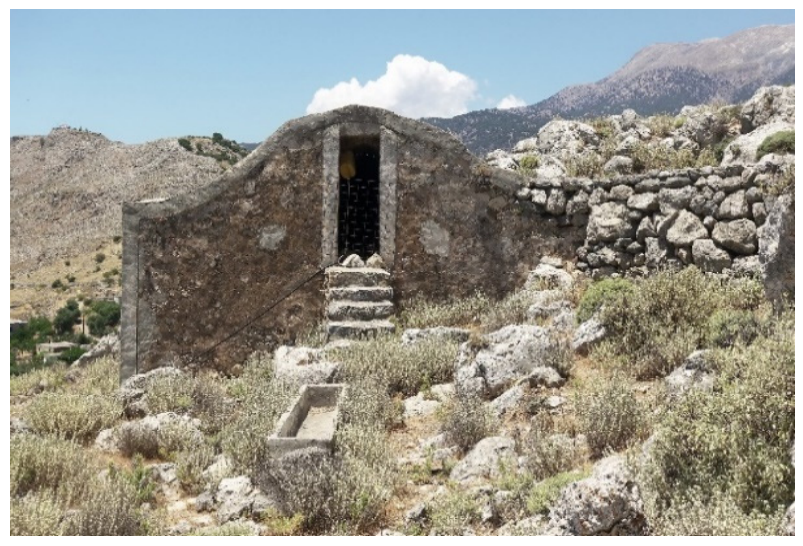

(a)

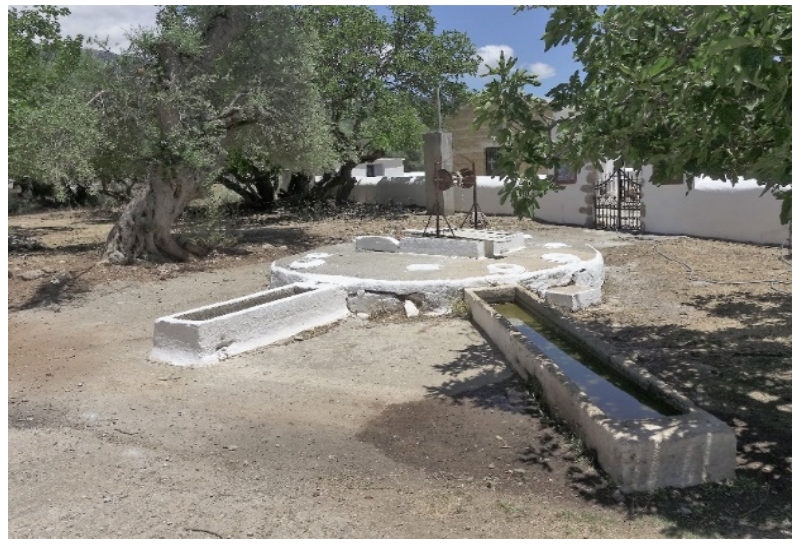

(b)

Figure 12. Anopolis: (a) A Venetian cistern and (b) a well in plateau in the neighborhood Gyros (photos by A. N. Angelakis). 
The Anopolis' plateau is very similar to that of Askyfou, very fertile and still feeds the inhabitants of the community. Moreover, its shallow aquifer has been used for water supply of the community through the centuries. A well of about $20 \mathrm{~m}$ in depth used for pumping of groundwater is shown in Figure $12 \mathrm{~b}$. Such as a well exist in each neighborhood of the village.

(c) LC Chora of Sfakia: The city of Chora is located on the south coast of Western Crete, near the end of the beautiful gorge of Imvros. During the Venetian occupation, the settlement was referred to as Obrosgialos; in the following years, it was called Sfakia and finally acquired its current name. It is the capital of the municipality, with 265 inhabitants in 2011.

The water supply of the city since the Venetian time was based in the rainwater harvesting and storage in cisterns. Such as a cistern is located in the eastern place of the city, in the Venetian castle (Figure 13a). Additionally, small springs were used for water supply since that time. Such a spring is located in the western coastal area of the city called vrysi (from the Greek word for "fountain") (Figure 13b). The water of that little coastal spring is still in use, as it is pumped into the water-supply network of the city.

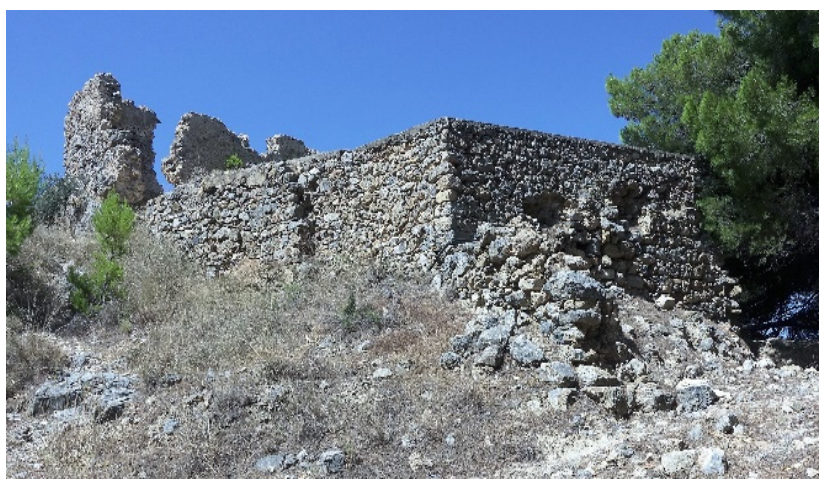

(a)

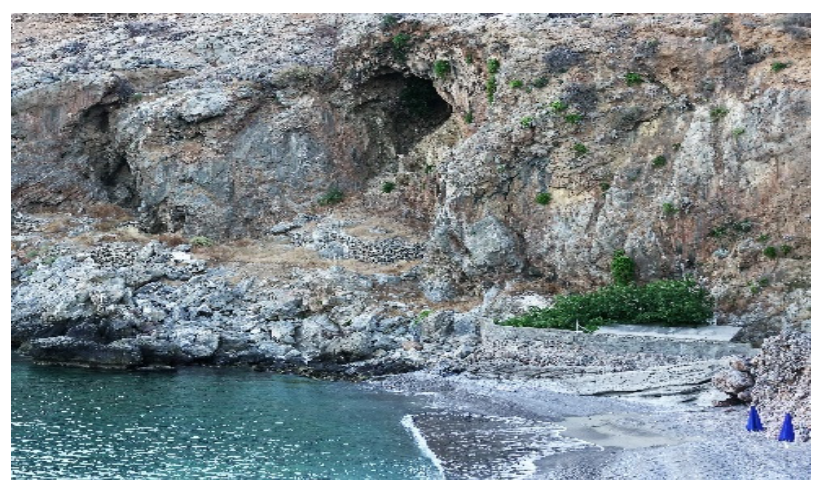

(b)

Figure 13. Water supply of Chora of Sfakia: (a) Venetian rainwater cistern and (b) costal spring (photos by A. N. Angelakis).

(d) In Asfentou, there are numerous rainwater cisterns. Before World War II, there were over 100 cisterns. Each family had at least one cistern. Most of them were made by stone with a special cleaning entrance (Figure 14a). In the village of Vouva, the water supply was based on rainwater cisterns. There were family and community cisterns. A community one located at the western entrance of the settlement, approximately $50 \mathrm{~m}$ from the main road, is shown in Figure 14b. It was rebuilt in 1935 on a pre-existing one. In Imvros there are in the same place, at the eastern end of the settlement, 4-5 square cisterns/wells, a few meters away from each other and of an average depth of $15 \mathrm{~m}$ (Figure 14c). Each belonged to a family. Finally, a rainwater cistern with a dome is found right at the entrance to the settlement of ancient Aradena, shown in Figure 14d.

The water supply of settlements at low altitudes was based on surface water sources, mainly natural springs, even with small supplies, and supplementary in rainwater harvesting and storage practices, such as in Argoules, AgiaRoumeli and Chora. The water supply of the Argoules settlement, for many years, was based on a fountain that existed at the southern end of the settlement (Figure 15a). It was also used for washing clothes and watering animals. Similarly, in the Kapsodasos settlement, there was a water-supply fountain at the western entrance of the settlement at a distance of about $50 \mathrm{~m}$ on the north side of the road (Figure 15b). In addition, rainwater cisterns of family type were used (Figure 15c). Finally, for many years the water supply of the settlement of Kallikratis was based on a fountain that exists in the central square of the village (Figure 15d). The fountain was supplied by small springs located at Kamali and Sochora places in northeastern of the 
settlement and at a distance of $1.5 \mathrm{~km}$ from it. These springs are still, today, the main water supply of the village. The fountain is currently being renovated. The aquifer under the Kallikratis' plateau is very poor, and it is not used for water supply. However, it is partially used for irrigation. In addition, rainwater cisterns of family type were for supplementary use. Similar fountains were in Patsianos and Skaloti settlements.

(e) LC Agia Roumeli: The water supply of the old settlement of Agia Roumeli, as well as the newer one, was based on springs of the gorge of Samaria. For this purpose, stone made terracotta conduits, and, recently, PVC pipes have been used.

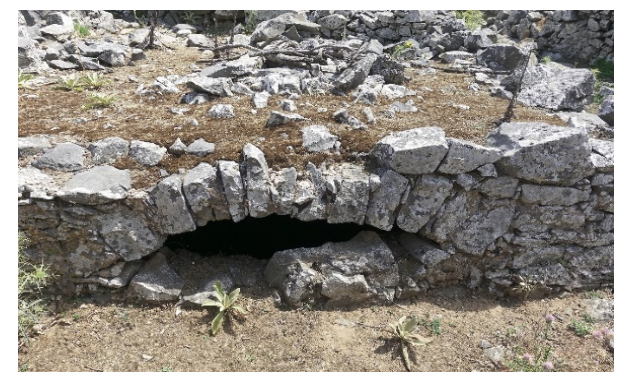

(a)

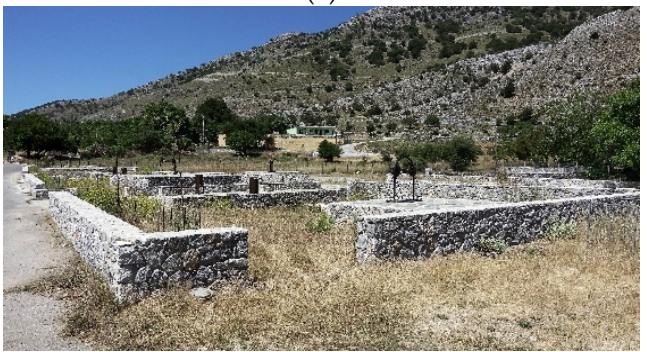

(c)

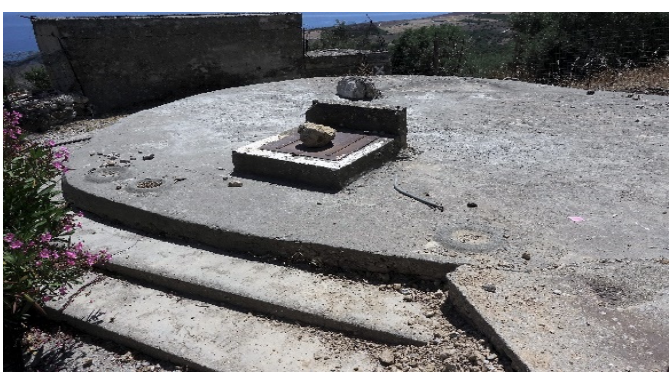

(b)

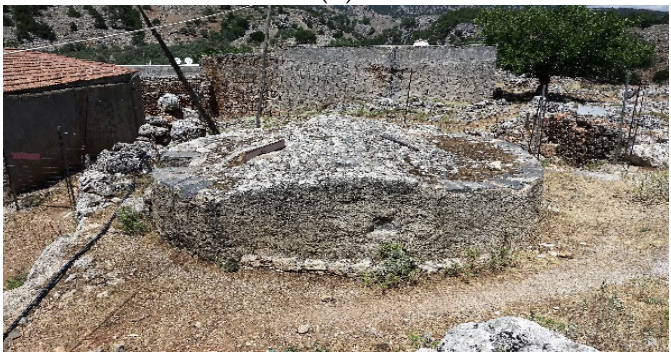

(d)

Figure 14. Rainwater cisterns in four settlements: (a) Asfentou, (b) Vouva, (c) Imbros and (d) Aradena (photos by A. N. Angelakis).

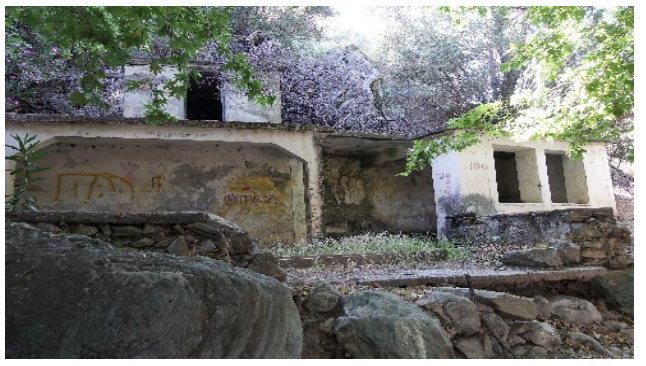

(a)

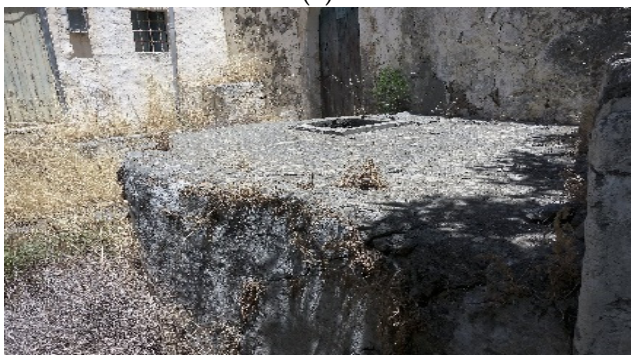

(c)

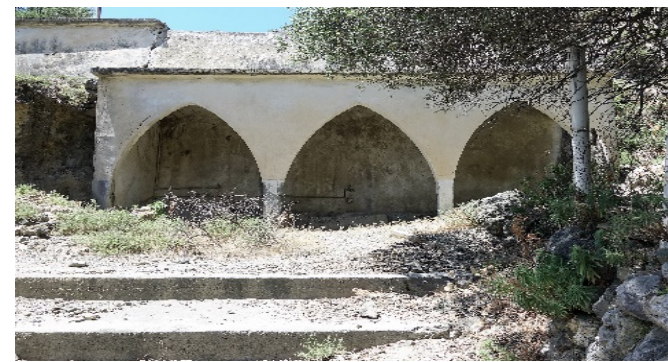

(b)

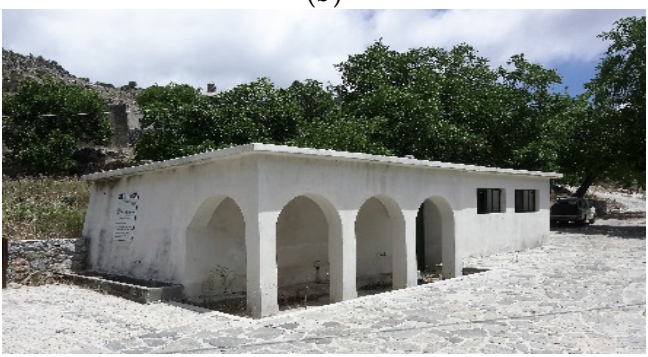

(d)

Figure 15. Water supply of settlements at low altitudes: (a) fountain in Argoules, (b) fountain Kapsodasos, (c) rainwater cistern Kapsodasos and (d) fountain in Kallikratis (photos by A. N. Angelakis). 


\section{Current Water Management and Water Supply in the Area of Sfakia: Problems and Future Challenges}

\subsection{Water Management and Water Supply}

Water management in the area of Sfakia, as a part of the island of Crete, is governed by the Water Frame Directive (WFD) 2000/60/EC involving a complex stakeholder network of national, regional, and local agencies [56]. The area is also covered by other supportive directions and measures of the EU enclosed either within the framework of the EU CAP 2014-2020 or measures for climate fluctuations [57]. Currently, water supply in the area is satisfied by pumping groundwater from great depths or even transport groundwater for water supply and other uses from areas of neighboring municipalities, and this is the main problem for water management in the area. For instance, the LC of Askyfov is supplied with water from the Vrysses area of Apokorona basin, where there is an underground karst aquifer, from which water is provided by the drillings in Vrysses and other neighboring settlements (located at a distance of $15 \mathrm{~km}$ and altitude $-700 \mathrm{~m}$ ), with water supplies from 60 to $4 \mathrm{~m}^{3} / \mathrm{d}$. The total volume of pumped water is about $2 \times 10^{6} \mathrm{~m}^{3}$ mainly during the irrigation period [58].

\subsection{Current and Future Challenges}

Water management in the area of Sfakia, as in many other individual areas of the island, faces the significant challenge to match status of low water availability with the need to satisfy the ever-increasing cases' water demands, driven by different economic activities (i.e., agricultural, domestic and livestock use), especially during the summer, due to increased residential and agricultural needs [23]. At the same time, it is also very crucial to maintain the quality of landscape and preserve the underground and surface water resources [59]. These goals are challenged further by climate variability [60-62] and the mountainous terrain of the area [63], stressing further the biodiversity and the status water resources $[64,65]$ and, subsequently, the economic development of the area (e.g., agricultural production) [66-68]. Finally, there are recorded chronic problems in water management, either regional or local scale, such as the legislation, bureaucracy and severe barriers in implementation of the existing water-management plans $[56,69]$, which urgently need to be addressed [23].

Despite the high precipitation of the Sfakia area (Figure 4), water availability remains critically low for meeting water needs during the summertime. The distinct terrain relief and geological formations of the area, which were discussed in previous sections, are identified as the principal causes preventing water retention and storage and stimulating losses to the sea through runoff and/or underground discharges. Regarding surface water resources, they are mainly in the form of ephemeral rivers, and they do not have an important contribution in meeting water demands during the dry period. Climate change is expected to further exacerbate the pressure on the availability of water resources in the study the area by increasing the frequency and intensity of droughts and heatwaves posing additional problems in the rural development of the area. Rural development poses a critical challenge, and it is tightly linked with the agricultural development and remains a priority of EU. Unfortunately, we lack records of water-resources monitoring, quantitative and qualitative to determine precisely the size of pressure in surface and subsurface waters and how it will evolve in the future. Although, from a theoretical point of view, several measures can be applied to alleviate the deficit in water availability (conservation tillage, small dumps, aquifer recharge, modern irrigation systems and effluent reuse), detailed data on the spatial distribution of water availability and demands are required to make decisions for the most proper measures. It is also important to update the existing water management by authorities and organizations; so far, there are indications of inefficient monitoring and control of water consumption by local organizations, while incentives or other promoting strategies are lacking [23].

The surface water resources of the area (mainly ephemeral rivers) are not sufficient to satisfy requirements of water users necessitating the need to update the existing water- 
management practices by considering new water sources and improvements in water-use efficiency. This fact raises risks for the quality of water resources. We, however, lack records of water-resources monitoring, whether quantitative and qualitative, to determine precisely the size of pressure in surface and subsurface waters. Several measures have been proposed to protect water resources, such as reduction of water consumption and increase water efficiency (WUE) by the main users, i.e., domestic (touristic included) and agriculture, including application of high-tech technologies in the distribution and consumption of water, such as adoption of accurate or deficit irrigation practices in agriculture [5]. It is also important to improve the water management by authorities and organizations; so far, there are indications of inefficient monitoring and control of water consumption by local organizations, while incentives or other promoting strategies are lacking [23].

The exploitation of alternative (non-conventional) water resources in the Sfakia area may particularly alleviate the gap between availability and demand. Currently, the Municipality of Sfakia lacks plans for water recycling. Uncertainties arising from potential risks to public health and the lack of estimates regarding the economic benefits are probably among the main reasons of that, keeping public acceptance of alternative water resources low; this a common trend for the island and the country as a whole, as discussed also in previous studies $[9,23,70]$. However, the current developments in wastewater treatment, together with the increased geographical distribution of WWTP all over the island and/or the deployment of decentralized and small on-site systems in the area, and threads by climatic variability, may reverse this trend and increase interest in the near future [23,71].

Due to high precipitation rates, the area of Sfakia may be vulnerable to floods (presence of steep river basins and narrow gorges), as presented here and elsewhere [63]. Moreover, a potential increase in temperature due to climate variability may cause additional impacts on ecosystems functioning and overall water balance in the area. Therefore, a strategic plan and measures, especially in agriculture and tourism, as important productive sectors of the area and the island of Crete, is needed. Such a plan should be tailored to local geography and prevailing land uses and classified according to their environmental and economic impact [68]. Moreover, the area, and the rest of the island, should be systematically monitored, incorporating high spatial and temporal resolution in the climate and hydrometric records, in order to predict and manage current and future challenges in most vulnerable sites of the area.

Taken together, and under the vision for the Sfakia Municipality "aeiforos" ("sustainable") development, it is important to secure sustainable water supply for all users to support further developments in economy, society and environment. This requires the exploitation as much as possible of adequate rainfall of the wider "Lefka Ori" area, as well as preparations on local, regional and national scale to prevent failures in water management. An option would be an appropriate "Water Resources Management Scheme", proportional to the relevant four main successful "Water Resources Master Plans" of Crete. The latter are based on the evaluation of alternative scenarios, derived from the results of innovative scientific research, targeting to provide the environmentally and value engineering optimal design, in accordance with the European Union's water requirements and directives [12,13]. A recent review study (Tzanakakis et al. 2020a) identified and summarized the main challenges in the (local) water management of Crete (many of which fit perfectly with the situation of Sfakia), proposing an integrated water-management plan (IWMP) for the Island of Crete. For this purpose, it was suggested to consider the current water-management plans for the River Basin District (RBD) of the Island updated by new strategies and measures of governance and stakeholders and research findings. They also proposed specific strategies and measures, such as (a) strict monitoring of water resources; (b) monitoring and prohibitions for end users; (c) adoption of WUE practices by users, especially farmers, based on current technological innovations; and (d) exploring reuse and alternative water resources (e.g., wastewater, rainwater and desalinated water), where possible. The latter should be supported by regulatory adjustments and provision of information for 
users. Such practices would facilitate the transition to climate and environmentally friendly agriculture and mitigate the potential effects of climatic fluctuations.

\section{Epilogue}

The high infiltration and permeability, including, of course, the relevant high evaporation rate of the karstified carbonates in Crete, Greece, as in other areas of the world, are associated with the development in the carbonate rocks of a network of interconnected karst conduits. This karstification extends below the present sea level and most likely happened during geological periods of lower sea level than at present. The karstification below the current sea level opened the way for the groundwater discharge directly to the sea, deeper than the sea level, and is might explain the scarcity of karst springs in Sfakia, despite the high precipitation. The identification of remarkably extensive karsts that receive large volumes of water from atmospheric precipitation is needed, as well as specialized investigations to exploit them. Considering also the potent ones with the salinization phenomena, systematic hydrogeological studies and investigations will contribute to the development of the proper solution for facing the water supply and irrigation requirements. In the case of the Sfakia Municipality, the hydrogeological system, with limited relevant hydrological data and studies, is creating problems regarding facing water uses.

The region of Sfakia has a complex geological background, mainly of different karst formations. The rainwater falling on the "Lefka Ori" Mountains and the contributed amounts from snow melting percolate through the limestone masses creating at the medium-upper layers of the unit the most significant hydrogeological setting, which refers to the formation of significant underground aquifers, while the remaining flows down to the south and north shores of the island.

Today, under the vision for the Sfakia Municipality "aeiforos" ("sustainable") development, it is important to secure the required quantities of water, since any further development depends on it. Unfortunately, despite adequate rainfall in the wider "Lefka Ori" area, the shortage of available water resources for its further development is today an unpleasant reality. The main causes of are (a) the geology and steep terrain of the area and (b) the temporal and spatial variations of precipitation resulting in removal of the water toward the sea and the north part of the west area of the island. To overcome the problem of water shortage now and in the future and to preserve water resources, specific options are suggested, such as the development of an Integrated Water Management Plant (IWMP) or "Water Resources Management Scheme", proportional to the relevant four main successful "Water Resources Master Plans" of Crete. Moreover, improvement of the infrastructure and facilities, as well as water-resources monitoring and high water-use efficiency (WUE) practices, are needed to control water consumption and prevent losses. Finally, consideration of alternative water resources (e.g., wastewater treatment and reuse, rainwater collection and storage, and desalination), as a complementary option, is also suggested.

Overall, the findings and discussion in this case study, which highlights the geological setting and the geomorphology as critical factors of available water resources of an area, may help to establish a discussion for similar cases worldwide and provide a framework of approaching scientifically analogous problems.

Author Contributions: A.N.A. had the original idea and mainly contributed to preparing the first draft emplacing prolegomena, history of water supply and water supply in modern times; V.A.T. contributed to prolegomena, water management and supply, and epilogue sections and edited and reviewed the manuscript; A.P. contributed to physical-setting section (especially in geology section) and to editing of the manuscript; E.L. contributed to physical-setting section (especially in climate section); E.A.V. contributed to physical-setting section (especially in hydrogeology); N.V.P. contributed to prolegomena, water management and supply, and epilogue sections and edited and reviewed the manuscript; and G.F. contributed to physical-setting section (especially in geology section). All authors have read and agreed to the published version of the manuscript.

Funding: This research received no external funding. 
Acknowledgments: Information and comments/corrections provided by Em. Steiakakis and E. Chiotis are gratefully acknowledged.

Conflicts of Interest: The authors declare no conflict of interest.

\section{References}

1. Tramblay, Y.; Llasat, M.C.; Randin, C.; Coppola, E. Climate change impacts on water resources in the Mediterranean. Reg. Environ. Chang. 2020, 20, 83. [CrossRef]

2. Morote, Á.-F.; Olcina, J.; Hernández, M. The Use of Non-Conventional Water Resources as a Means of Adaptation to Drought and Climate Change in Semi-Arid Regions: South-Eastern Spain. Water 2019, 11, 93. [CrossRef]

3. Malek, Ž.; Verburg, P.H.; Geijzendorffer, I.R.; Bondeau, A.; Cramer, W. Global change effects on land management in the Mediterranean region. Glob. Environ. Chang. 2018, 50, 238-254. [CrossRef]

4. Ait-Mouheb, N.; Mayaux, P.-L.; Mateo-Sagasta, J.; Hartani, T.; Molle, B. Chapter 5-Water reuse: A resource for Mediterranean agriculture. In Water Resources in the Mediterranean Region; Zribi, M., Brocca, L., Tramblay, Y., Molle, F., Eds.; Elsevier: Amsterdam, The Netherlands, 2020; pp. 107-136. [CrossRef]

5. Tzanakakis, V.A.; Paranychianakis, N.V.; Angelakis, A.N. Water Supply and Water Scarcity. Water 2020, 12, 2347. [CrossRef]

6. Cramer, W.; Guiot, J.; Fader, M.; Garrabou, J.; Gattuso, J.-P.; Iglesias, A.; Lange, M.A.; Lionello, P.; Llasat, M.C.; Paz, S. Climate change and interconnected risks to sustainable development in the Mediterranean. Nat. Clim. Chang. 2018, 8, 972-980. [CrossRef]

7. Molina, M.O.; Sánchez, E.; Gutiérrez, C. Future heat waves over the Mediterranean from an Euro-CORDEX regional climate model ensemble. Sci. Rep. 2020, 10, 8801. [CrossRef] [PubMed]

8. Russo, A.; Gouveia, C.M.; Dutra, E.; Soares, P.M.M.; Trigo, R.M. The synergy between drought and extremely hot summers in the Mediterranean. Environ. Res. Lett. 2019, 14, 014011. [CrossRef]

9. Chartzoulakis, K.S.; Paranychianakis, N.V.; Angelakis, A.N. Water resources management in the Island of Crete, Greece, with emphasis on the agricultural use. Water Policy 2001, 3, 193-205. [CrossRef]

10. Mascaro, G.; Viola, F.; Deidda, R. Evaluation of Precipitation From EURO-CORDEX Regional Climate Simulations in a Small-Scale Mediterranean Site. J. Geophys. Res. Atmos. 2018, 123, 1604-1625. [CrossRef]

11. Koshida, G.; Cohen, S.; Mortsch, L. Climate and water availability indicators in Canada: Challenges and a way forward. Part I -Indicators. Can. Water Resour. J. Rev. Can. Des Ressour. Hydr. 2015, 40, 133-145. [CrossRef]

12. Pavlakis, P. The major Hydraulic Projects of Crete. In Proceedings of the Available Water Resources Projects' Management. Workshop on "Dams and Reservoirs in Crete: Design, Construction \& Management of Large Hydraulic Works." OAK, Heraklion, Crete, 21 March 2014; 2014. (In Greek)

13. Pavlakis, P.; Pavlaki, A. Water Resources Planning \& Management Schemes of Crete. Potential for increasing available water resources in western Crete. In Proceedings of the 11th ICOLD European Club Symposium, Chania, Greece, 2-4 October 2019.

14. Pavlakis, P. A Contribution to the Hydrogeological Investigation of the Calcareous Aquifer of Agyia Springs, West Crete. Ph.D. Thesis, School of Civil Engineering, Aristotle University of Thessaloniki, Thessaloniki, Greece, 1989. (In Greek)

15. Pavlakis, P.; Lydakis, A.P.; Simantiris, N. Exploitation of the important Water Resources in Chania Prefecture, in order to meet the Irrigation \& Water Supply demands. In Proceedings of the Conference Promotion of Development \& Environmental Infrastructure Projects-ESPA 2007-2013, Technical Chamber of Greece, Department of Western Crete, Chania, Crete, 30-31 January 2010. (In Greek)

16. Kalantzis, K. Tradition in the Frame: Photography, Power, and Imagination in Sfakia, Crete; Indiana University Press: Bloomington, IN, USA, 2019.

17. Mountrakis, D.; Kilias, A.; Pavlaki, A.; Fassoulas, C.; Thomaidou, E.; Papazachos, C.; Papaioannou, C.; Roumelioti, Z.; Benetatos, C.; Vamvakaris, D. Neotectonic study of Western Crete and implications for seismic hazard assessment. J. Virtual Explor. 2012, 42, 2. [CrossRef]

18. Pavlaki, A. Engineering Geological Conditions in Chania Prefecture, Crete Island. Ph.D. Thesis, School of Civil Engineering, Aristotle University of Thessaloniki, Thessaloniki, Greek, 2008. (In Greek)

19. Pavlaki, A.; Meladiotis, I.; Pavlakis, P. Applicability of the "Lefka Ori” Western Crete region “GeoFactors” Interaction Matrix (GFIM) as a key to understanding the engineering geological condtions. Bull. Geol. Soc. Greece 2013, 47, 1820-1833. [CrossRef]

20. Adamopoulos, K. 1000 and 1 caves in "Lefka Ori" massif, on Crete, Greece. In Proceedings of the 16th International Congress of Speleology, Brno, Czech Republic, 21 July 2013; pp. 21-28.

21. Fytrolakis, N. The geological Structure of Crete. Bachelor's Thesis, National Technology University of Athens, Athens, Greece, 1980. (In Greek)

22. Plymakis, A. Caves in Chania Area: Some Beautiful and Interesting Caves; Book; Plymakis: Chania, Greece, 2002; 417p.

23. Tzanakakis, V.; Angelakis, A.; Paranychianakis, N.; Dialynas, Y.; Tchobanoglous, G. Challenges and Opportunities for Sustainable Management of Water Resources in the Island of Crete, Greece. Water 2020, 12, 1538. [CrossRef]

24. AGI. American Geological Institute. Karst, a Renewable Water Resource in Limestone Rocks, Encyclopedia of the Environment. 1972. Available online: https://www.encyclopedie-environnement.org/en/water/karst-renewable-water-resource-in-limestonerocks/ (accessed on 20 October 2021). 
25. Johnson, T.C. Origin of sedimentary rocks (Second edn.), H. Blatt, G. Middleton, and R. Murray, Prentice-Hall, Inc., 1980. Earth Surf. Processes Landf. 1981, 6, 97. [CrossRef]

26. Abdullah, F.H. Porosity and permeability of karst carbonate rocks along an unconformity outcrop: A case study from the Upper Dammam Formation exposure in Kuwait, Arabian Gulf. Heliyon 2021, 7, e07444. [CrossRef]

27. Thornbury, W.D. Principles of Geomorphology, 2nd ed.; Wiley: New York, NY, USA, 1969; pp. 303-344; ISBN 0471861979.

28. Smith, D. Landforms of Alberta; Interpreted from Airphotos and Satellite Imagery. Alberta Remote Sensing Center. Alta. Environ. Publ. 1987. Available online: .https://www.worldcat.org/title/landforms-of-alberta-interpreted-from-airphotos-and-satelliteimagery/oclc/24706971 (accessed on 20 October 2021).

29. Available online: https://en.wikipedia.org/wiki/Karst\#/media/File:Limestone_Eocene_deposit_at_Sinj_Stari_grad_-_ Dalmatia_-_Croatia_IMG_20210820_083857.jpg (accessed on 10 January 2022).

30. Bakalowicz, M. Karst at depth below the sea level around the Mediterranean due to the Messinian crisis of salinity. Hydrogeological consequences and issues. Geol. Belg. 2014, 17, 96-101.

31. Bonacci, O.; Fistanic, I.; Split, C. Contribution to hydrological analysis of the coastal karst spring Almyros (Crete, Greece). In Proceedings of the Conference on Water Observation and Information System for Decision Support, Balwois, Ohrid, FYROM, UNDP-Agency of Skopje, Crete, Greece, 25-29 May 2004; pp. 191-192.

32. Voudouris, K.; Alexopoulos, A.; Antonakos, A.; Kallergis, G. Water Resources in the wider area of the Aposelemis Basin, Crete Island, Greece. Bulletin of the Geological Society of Greece. In Proceedings of the 11th International Congress, Athens, Greece, 24-26 May 2007.

33. Kazakis, N.; Chalikakis, K.; Mazzilli, N.; Ollivier, C.; Manakos, A.; Voudouris, K. Management and research strategies of karst aquifers in Greece: Literature overview and exemplification based on hydrodynamic modelling and vulnerability assessment of a strategic karst aquifer. Sci. Total Environ. 2018, 643, 592-609. [CrossRef]

34. Steiakakis, E. Evaluation of Exploitable Groundwater Reserves in Karst Terrain: A Case Study from Crete, Greece. Geosciences 2018, 8, 19. [CrossRef]

35. Agou, V.D.; Varouchakis, E.A.; Hristopulos, D.T. Geostatistical analysis of precipitation in the island of Crete (Greece) based on a sparse monitoring network. Env. Monit Assess 2019, 191, 353. [CrossRef]

36. Varouchakis, E.A.; Corzo, G.A.; Karatzas, G.P.; Kotsopoulou, A. Spatio-temporal analysis of annual rainfall in Crete, Greece. Acta Geophys. 2018, 66, 319-328. [CrossRef]

37. Pavlaki, A.; Perlreros, V.; Fasoulas, C.; Lionis, M.; Lioni, A.; Mountrakis, D.; Kilias, A.; Thomaidou, E.; Pavlakis, P.; Goumenaki, P.; et al. Geological study and relevation of the Lefka Ori Crete mountains geoenviroment dynamism. In Proceedings of the 3rd International Geo-Cultural Symposium "Samaria 2016", Chania/Crete, Greece, 13-15 May 2016.

38. Kilias, A. Late Orogenic Extension in the Hellenic Orogen. In Proceedings of the 9th International Congress, Athens, Greece, September 2001; pp. 149-156.

39. Mountrakis, D. Orogenic evolution on the Hellenic Orogen.Geometry \& Kinematics. In Proceedings of the 9th International Congress, Athens, Greece, 3 September 2001; pp. 2113-2126.

40. Ten Veen, J.H.; Kleinspehn, K.L. Incipient continental collision and plate-boundary curvature: Late Pliocene-Holocene transtensional Hellenic forearc, Crete, Greece. J. Geol. Soc. 2003, 160, 161-181. [CrossRef]

41. Mountrakis, D.; Kilias, A.; Pavlaki, A.; Fassoulas, C.; Thomaidou, C. Neotectonic Study of the Northern Part of Western CreteNeotectonic \& Geological Map Sc. 1:50.000; Inter-Municipal Cooperation between 11 Municipalities of the Chania Prefecture; Department of Geology, Aristotle University of Thessaloniki: Thessaloniki, Greece, 2004.

42. Fassoulas, C.; Kilias, A.; Mountrakis, D. Postnappe stacking extension and exhumation of high-pressure/low-temperature rocks in the island of Crete, Greece. Tectonics 1994, 13, 127-138. [CrossRef]

43. Kilias, A.; Fassoulas, C.; Mountrakis, D. Tertiary extension of continental crust and uplift of Psiloritis metamorphic core complex in the central part of the Hellenic Arc (Crete, Greece). In Active Continental Margins_Present and Past; Giese, P., Behrmann, J., Eds.; Springer: Berlin/Heidelberg, Germany, 1994.

44. Seidel, E.; Kreuzer, H.; Harre, W. A late Oligocene/early Miocene high pressure belt in the external Hellenides. Geol. Jahrbuch. Reihe E Geophys. 1982, 23, 165-206.

45. IGSR. Institute for Geology \& Subsurface Research, 1969, 1971. Geological Map of Greece. Sc. 1:50.000. Sheet Alikianou (1969) by Tataris \& Christodoyloy. Sheet Chania (1971) by Karageorgiou. 1969.

46. Pavlaki, A.; Mountrakis, D.; Kilias, A. Geological Map Sc 1:25.000 E Geological Study of the Northwestern Part of the Lefka Ori Mountains Area; Technical University of Crete: Chania, Greece, 1990. (In Greek)

47. Demiris, K.; Meladiotis, I. Investigation of the Myloniana Karstic aquifer (northern part of the Lefka Ori Mountains-West Crete), for the determination of boreholes drilling positions in the framework of the ground water exploitation. Technical Report; OADYK: Chania, Greece, 1983. (In Greek)

48. Meladiotis, I.; Dermisis, B.; Pavlakis, P. Groundwater flow mechanism of the Agyias springs—Lefka Ori Mountains carbonated karst aquifer system in Western Crete. In Proceedings of the 5th Conference of the Hellenic Hydrotechnical Association, Larissa, Greece, 9-12 November 1992; pp. 259-266.

49. Pavlakis, P. Master Plan of the Water Resources' Hydraulic Projects along the Northern Zone of the Island of Crete; Technical Study \& Maps, Prefecture of Crete: Heraklion, Greece, 1999. 
50. Demiris, K.; Meladiotis, I.; Pavlakis, P. Map of Tectonic Discontinuities of the Island of Crete E Hydrological Data. Sheet: Crete, Sc. 1:200.000; OADYK—Laboratory of Engineering Geology, Department of Civil Engineering AUTh: Thessaloniki, Greek, 1992. (In Greek)

51. Leveque, P. Rapport de Synthèse Sur Les Études Effectuées par Télédétection et Analyses Isotopiques, en Crète Occidentale; Lab.Rad.\& Mec.Roches, Université de Bordeaux: Bordeaux, France, 1973; pp. 1-25.

52. Leveque, P. Crète Occidentale-Carte Thermographique; L.R.M.R.; Université de Bordeaux: Bordeaux, France, 1974.

53. Leveque, P. Hydrogéologie Karstique et Télédétection: Utilisation de la Télédétection et du Tritium Pour l Établissement du Premier Inventaire des Ressources Hydrologiques en Crète Occidentale; t 283 Série D; C. R. Acad. Sc. Paris: Paris, France, 1976; pp. 1025-1028.

54. Pavlakis, P.; Mpletsas, A.; Kountouris, S.; Yiotis, A.; Vounousakis, D.; Tetraktys; Fragidakis, D.; Karavokiris, G.; Daoutis, I.; Eythimiatos, I. Development of Water Resources for Irrigation \& Water Supply in Western Crete. Final Studies; Ministry of Public Works, 1978, 1980, 1982; Hydraulic Works Department. Directorate of Studies: Athens, Greece, 1983. (In Greek)

55. Fragouli, A. Province of Sfakion; Ministry of Environment: Athens, Greece, 1997; p. 260.

56. CMD. Common Ministerial Decision. Management Plan as a River Basin of the Water Region of Crete; No 896, ФEK B/4666/2017; Ministry of Environment, Energy and Climate Change: Athens, Greece, 2017. (In Greek)

57. EEA. European Environment Agency. Report No 6. Tracking Progress towards Europe's Climate and Energy Targets until 2020. In Trends and Projections in Europe 2014; 2014. Available online: https:/ / www.eea.europa.eu/publications/trends-and-projectionsin-europe-2014 (accessed on 20 October 2021).

58. Koutsoyiannis, D.; Zarkadoulas, N.; Angelakis, A.N.; Tchobanoglous, G. Urban water management in Ancient Greece: Legacies and lessons. J. Water Resour. Plan. Manag. 2008, 134, 45-54. [CrossRef]

59. Ispikoudis, I.; Lyrintzis, G.; Kyriakakis, S. Impact of human activities on Mediterranean landscapes in western Crete. Landsc. Urban Plan. 1993, 24, 259-271. [CrossRef]

60. Jacob, D.; Kotova, L.; Teichmann, C.; Sobolowski, S.P.; Vautard, R.; Donnelly, C.; Koutroulis, A.G.; Grillakis, M.G.; Tsanis, I.K.; Damm, A.; et al. Climate Impacts in Europe Under $+1.5^{\circ} \mathrm{C}$ Global Warming. Earth's Future 2018, 6, 264-285. [CrossRef]

61. Vautard, R.; Gobiet, A.; Sobolowski, S.; Kjellström, E.; Stegehuis, A.; Watkiss, P.; Mendlik, T.; Landgren, O.; Nikulin, G.; Teichmann, C. The European climate under a 2 C global warming. Environ. Res. Lett. 2014, 9, 034006. [CrossRef]

62. Tsanis, I.K.; Koutroulis, A.G.; Daliakopoulos, I.N.; Jacob, D. Severe climate-induced water shortage and extremes in Crete. Clim. Chang. 2011, 106, 667-677. [CrossRef]

63. Ruman, S.; Tichavský, R.; Šilhán, K.; Grillakis, M.G. Palaeoflood discharge estimation using dendrogeomorphic methods, rainfall-runoff and hydraulic modelling-A case study from southern Crete. Nat. Hazards 2021, 105, 1721-1742. [CrossRef]

64. Koutroulis, A.G.; Grillakis, M.G.; Daliakopoulos, I.N.; Tsanis, I.K.; Jacob, D. Cross sectoral impacts on water availability at $+2{ }^{\circ} \mathrm{C}$ and $+3^{\circ} \mathrm{C}$ for east Mediterranean island states: The case of Crete. J. Hydrol. 2016, 532, 16-28. [CrossRef]

65. Koutroulis, A.G.; Tsanis, I.K.; Daliakopoulos, I.N.; Jacob, D. Impact of climate change on water resources status: A case study for Crete Island, Greece. J. Hydrol. 2013, 479, 146-158. [CrossRef]

66. Brilli, L.; Lugato, E.; Moriondo, M.; Gioli, B.; Toscano, P.; Zaldei, A.; Leolini, L.; Cantini, C.; Caruso, G.; Gucci, R.; et al. Carbon sequestration capacity and productivity responses of Mediterranean olive groves under future climates and management options. Mitig Adapt. Strateg. Glob Chang. 2019, 24, 467-491. [CrossRef]

67. Chartzoulakis, K.; Psarras, G. Global change effects on crop photosynthesis and production in Mediterranean: The case of Crete, Greece. Agric. Ecosyst. Environ. 2005, 106, 147-157. [CrossRef]

68. Georgopoulou, E.; Mirasgedis, S.; Sarafidis, Y.; Vitaliotou, M.; Lalas, D.P.; Theloudis, I.; Giannoulaki, K.D.; Dimopoulos, D.; Zavras, V. Climate change impacts and adaptation options for the Greek agriculture in 2021-2050: A monetary assessment. Clim. Risk Manag. 2017, 16, 164-182. [CrossRef]

69. CMD. Common Ministerial Decision. Management Plan as a River Basin of the Water Region of Crete; No 163. ФEK 570/B'/2015; Ministry of Environment, Energy and Climate Change: Athens, Greece, 2015. (In Greek)

70. Menegaki, A.N.; Hanley, N.; Tsagarakis, K.P. The social acceptability and valuation of recycled water in Crete: A study of consumers' and farmers' attitudes. Ecol. Econ. 2007, 62, 7-18. [CrossRef]

71. Paranychianakis, N.V.; Salgot, M.; Snyder, S.A.; Angelakis, A.N. Water Reuse in EU States: Necessity for Uniform Criteria to Mitigate Human and Environmental Risks. Crit. Rev. Environ. Sci. Technol. 2015, 45, 1409-1468. [CrossRef] 